692

5) Formation and liberation of NEFA in and from the epididymal adipose tissues of alloxan diabetic rats showed an increase in proportion to the decreased glucose uptake. These metabolic disturbances of epididymal adipose tissues could be restored more or less by addition of glucose alone or glucose plus insulin to the incubation medium or through pretreatment of diabetic rats with insulin or D860. Addition of ACTH or hydrocortisone to the incubation medium invited further inhibition of glucose uptake and more liberation of NEFA possibly through the disturbance of fat synthesis. Metabolic behavior similar to this tendency was observed also in vivo experiments. Comparison of metabolic effects of insulin and D860 showed almost no difference in the above experiments.

6) The above mentioned studies seem to have disclosed a plausible co-operation of disturbed carbohydrate metabolism of adipose tissues in the patho-physiology of diabetes. This metabolic disturbance showed a favorable response to insulin and D860, whereas they responded to ACTH and cortisone etc. in quite a different manner. The author is of the opinion, that the metabolic disturbance in adipose tissues is an important clue in the study of type and physiology of diabetes.

\title{
Studies on the Separation and the Extraction of Anterior Pituitary Hormone by Paper-electrophoresis.
}

\author{
by
}

\section{Matsuto MOCHIZUKI}

Department of Obstetrics and Gynecology, Kobe Medical College (Director : Prof. Yasuo Ueda)

Separation and purification of pig's thyroid stimulating hormone and its molecular weight. (4th report)

Aceton dry powder of pig's anterior hypophysis were extracted with $2 \%$ saline water, and were centrifuged. The supernatant fluid was fractionated by continuous paper-electrophoresis (Condition: $26 \mathrm{~mA} / 35 \mathrm{~cm}$. 500v/40 cm, ionic strength 0.05, Phosphoric buffer $\mathrm{pH} 8.5$ ).

Each fraction was biologically assayed; TSH activity bv Greenspan's method, Gonadotropic activity by Florsheim's method, STH activity by Tibia-Test, and ACTH activity by Sayers-Munson's method. The fraction in the middle, TSH activity was clearly detected with slight gonadotropic activity. Other activities were not accounted. Contents of the fraction, in which TSH activity was revealed, were ultracentrifuged. The sedimentation curve was monophasic and the sedimentation constants was 2.28. Thus the molecular weight was calculated as about 20000.

Separation and purification of pig's pituitary gonadotropin and transmission of gonadotropic substances in vivo. (5th report)

In phosphate buffer solution, $\mathrm{pH} 4.5$, the extracted substances of aceton dry powder of pig's anterior hypophysis were separated by continuous paper-electrophoresis into six fractions. In this case, as it was anticipated on account of acid solution thyrotropic activity would be diminished and only gonadotropic activity would be remained, the gonadotropic activity was measured by weighing the ovaries, uterus, prostate and seminal vesicle of hypophysectomized immature rats and the ovaries were examined histologically. On the second and the third fraction, which are numbered from anod, gonadotropic activity was found. The $\mathrm{LH}$ action was recognized in the second fraction and the FSH action in the third fraction. 
NIH-FSH and NIH-LH which were introduced by Dr. Wilhelmi were also separeted by paperelectrophoresis, then NIH-FSH is separeted into two fraction, but NIH-LH separeted into only one fraction, so the purity of NIH-LH was confirmed.

Anteron was injected into hypophysectomized rat intravenously, ten minutes later blood was taken. The serum separeted by continuous paperelectrophoresis were examined for gonadotropic activity of each fraction by the method of weighing mouse uterus.

On gamma-globulin in the serum of rat, gonadotropic activity was recognized.

Separation and purification of urinary gonadotropin by continuous paperelectrophoresis. (6th report)

Crude gonadotropic substances of pregnant woman's urine and postmenopausal urine obtained by kaolin absorption method, were separeted into some fraction by continuous paperelectrophoresis (Condition: $26 \mathrm{~mA} / 35 \mathrm{~cm}, 450 \mathrm{v} / 40 \mathrm{~cm}$, ionic strength 0.05 , phosphate buffer solution, $\mathrm{pH} 4.5$ ).

Crude substance of postmenopasal woman's urine was separated into 3 fractions. Only in the first fraction, gonadotropic activity was revealed; its FSH-action was very strong, but its LH-action was very weak.

Crude substance of the pregnant woman's urine in the former half term was separated into four fractions. Gonadotropic activity was recognized in the first and the second fraction; The LH-action of it in the second fraction was stronger than that of the first fraction and FSH-action in the first fraction was stronger than that of the second.

Crude substance of the pregnant woman's urine in the later half term was separated into three fractions. In the first and second fraction of it gonadotropic activities were found, but FSH-action was a little weak comparing with that of the gonadotropic activity of the urine in the former half term.

Even in the case of human chorionic gonadotropin and postmenopausal gonadotropin, LH-action and FSH-action were not separated perfectly.

Comparison with TSH substances to gonadotropic substances. (7th report)

1) Differences by paperelectrophoric condition.

TSH activity exists only in the middle fraction fractionated in basic solvent, but in acid solvent thyrotropic activity is apt to be lost. On the other hand, gonadotropic activity was not lost even in acetic solvent and in basic solvent. Therefore, for separation, extraction and purification of TSH, any procedure under acetic solvent are not desirable.

2) Thyrotropic substances and gonadotropic substances in serum.

Both TSH activity and gonadotropic activity were recognized on gamma-globulin. It shows the similarity between these two proteohormones.

3) Physical chemical characteristics.

Sedimentation-coefficient of pig's purified TSH is $2.3 \mathrm{~S}$ and molecular weight is 20000 . On the other hand, gonadotropic substances (Steelman), molecular weight of sheep FSH is 25000-30000, and that of sheep LH is 30000 . So, gonadotropin consists of larger molecules than TSH.

4) Contamination of biological activity between TSH and Gonadotropin.

From our result of separation and purification of these two tropic substances by paperelectrophoresis, in basic solvent small amount of gonadotropic activity always contaminates of TSH activities. Bates' thyrotropin and in FSH and LH of NIH have approved the contamination with TSH and gonadotropin. Therefore, separating the two tropic hormones is very difficult, although the contamination is to be ascribed to the chemical similarity, the secondary biological actions of each other are to be considered.

Vol. 37 No. 7 


\title{
脳下垂体前葉ホルモンの濾紙電気泳動学的研究 及び分離抽出に関する研究
}

第 4 報 豚甲状腺刺戟ホルモンの分離精製と分子量について

\author{
神戸医科大学産婦人科教室 \\ 大学院学生 望 月 真 人
}

(昭和 36 年 9 月 19 日受付)

\begin{abstract}
緒
言

前報1では市販製品中に含まれる甲状腺刺㦸ホルモン（以下 TSH と略記）活性物質の分離精製法につい て報告した。本報では既報の基礎的研究をもととして連続濾紙電気泳動法により豚脳下垂体前葉から, 本物 質を分離精製し，混在が予想される他の tropic Hormone ${ }^{2}$ 即ち性腺刺㦸ホルモン (以下Gと略記)，副腎皮 質刺㦸ホルモン（以下 ACTH と略記）及び成長ホルモン（以下 STH と略記）の検定を行ない，又分離精 製した豚 TSH 活性物質の分子量についても結果が得られたので報告する。
\end{abstract}

\section{実験材料並びに実験方法}

\section{1) 実験材料}

実験材料としては豚下垂体前葉アセトン粉末，実験動物とは下垂体剔出幼若ラッテ及び初生雛を使用した。

\section{2）実験方法}

装置は既報の連続濾紙電気泳動装置を使用し，泳動条件は $26 \mathrm{~mA} / 35 \mathrm{~cm} ， 500 \mathrm{~V} / 40 \mathrm{~cm} ，$ Sörensen 緩衝液 $\mathrm{Na}_{2} \mathrm{HPO}_{4} \mathrm{KH}_{2} \mathrm{PO}_{4}$, イオン強度 $0.05, \mathrm{pH} 8.5$ で施行した.

透析にはビスキン膜，分子量測定には超遠心分離法を用い，精製豚 TSH 活性の検討は初生㮲倠甲状腺 $\mathrm{P}^{32}$ 摂取率法 ${ }^{3}$ によつた。

\section{実 験 成 績}

1) 分離精製法は前報と同様連続濾紙電気泳動法により Sörensen 緩偅液pH8.5, 東洋濾紙No52を使用する. 豚下垂体前葉アセトン粉末 $1 \mathrm{~g}$ を $2 \%$ 食 塩水 $3 \mathrm{cc}, 4{ }^{\circ} \mathrm{C}$ で泠浸抽出, 逗心分離後上澄 液を垂直角濾紙の中心部に絶えず少量宛毛細 管現象を利用して流下，泳動中は冷水を還 流，装置内温度を10度以下に保つ。

第 1 図は上記の結果を示し，それぞれ陽極 側，陰極側に移動する 7 分劃を得る。

染色は Amidoblack 10B, 脱色は $5 \%$ 酢酸 水を用い，10分間毎 3 回処理の後，5\%酶酸 溶液中に12時間放置する。

得られた各分劃を氷槽中で，夫々強力に攪 拌しつつ $99.5 \%$ エチールアルコール $\left(5{ }^{\circ} \mathrm{C}\right.$ 以 下）を添加，飽和度 $85 \%$ として15時間以上冷

第 1 図連続式濾紙電気泳動法に上る豚脳下 垂体抽出液の分離像

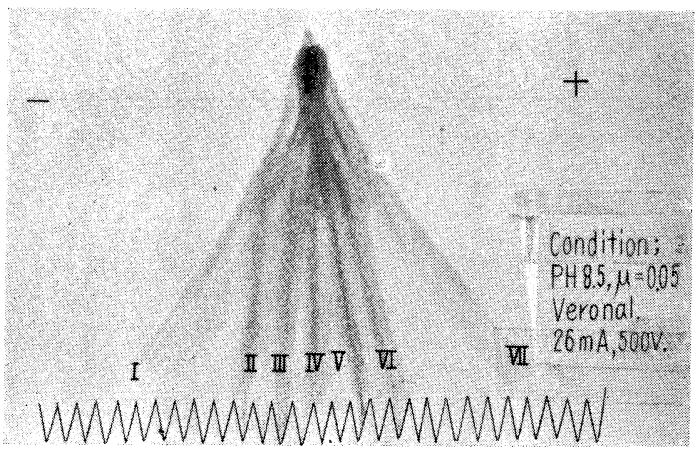


第 1 表 分離した各分劃から検体を調製するる方法 各分劃

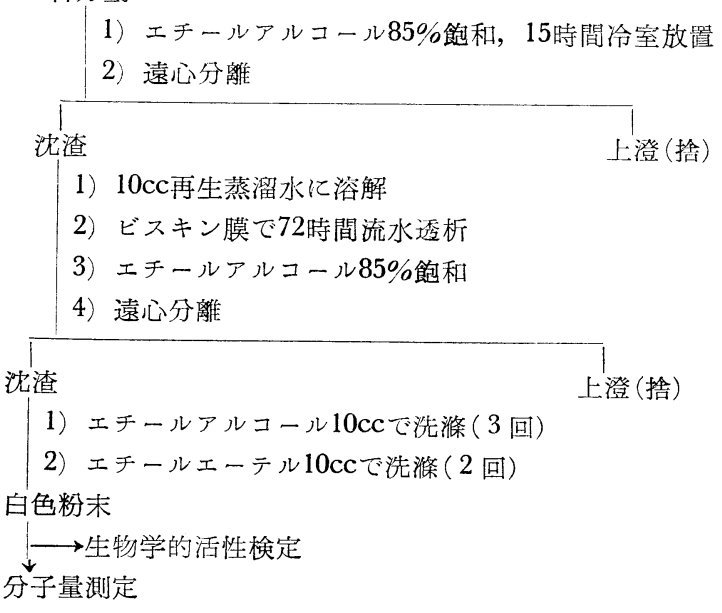

蔵厙中に静置，1 分間ほぼ3000〜4000回転 で10分間遠心沈搌，沈渣を得る。この沈查 中の塩類などを除去するために，沈渣を再 生蒸溜水10ccに溶解し，ビスキン膜で72時 間流水透析した後再び上記の要領でエチー ルアルコールにより再沈，遠心沈澱後夫々 $10 \operatorname{cc} の$ エールアルコールで数回洗滌, 更 にエチールエーテルで洗涤後, 減圧真空乾 燥を行ない 7 分劃より夫々白色の粉末を得 た.

第 1 表はこの要領を示す.

上記の 7 分劃より得た白色粉末を夫々 2 $\mathrm{mg}$ ずつ蒸溜水 $3 \mathrm{cc}$ に 溶解し, 各分劃毎の $\mathrm{TSH}$ 活性を Greenespan 法3)で, 又同時に Florsheim 法4)でG活性を測定した。

第 2 表 各分劃每の $\mathrm{TSH}$ 活性及び $\mathrm{G}$ 活性の測定值

\begin{tabular}{|c|c|c|c|c|c|c|c|c|}
\hline Gount/min 分劃 & 1 & 2 & 3 & 4 & 5 & 6 & 7 & 対照群 \\
\hline \multirow{5}{*}{$\begin{array}{c}\text { 甲状腺 } \mathrm{P}^{32} \text { 椇取率 } \\
(\mathrm{TSH} \text { 活性) }\end{array}$} & 81 & 74 & 74 & 125 & 80 & 97 & 70 & 79 \\
\hline & 61 & 60 & 94 & 138 & 92 & 90 & 98 & 57 \\
\hline & 54 & 91 & 85 & 120 & 93 & 77 & 73 & 66 \\
\hline & 51 & 107 & 88 & 99 & 96 & 107 & 96 & 69 \\
\hline & 62 & 82 & 101 & 131 & 86 & 83 & 72 & 82 \\
\hline \multirow{5}{*}{$\begin{array}{c}\text { 箤丸 } \mathrm{P}^{\mathrm{s} 2} \text { 摂取率 } \\
\text { (G活性) }\end{array}$} & 208 & 241 & 355 & 485 & 762 & 357 & 170 & 170 \\
\hline & 149 & 386 & 244 & 474 & 702 & 402 & 182 & 109 \\
\hline & 170 & 352 & 308 & 481 & 583 & 429 & 109 & 250 \\
\hline & 182 & 303 & 321 & 450 & 639 & 410 & 229 & 219 \\
\hline & 185 & 290 & 298 & 441 & 629 & 452 & 112 & 106 \\
\hline
\end{tabular}

第 2 表はこの結果を示す.

第 2 表によれば罹甲状腺内 $\mathrm{P}^{32}$ 摂取率の平均は 対照群の70 (Counts/min.) に対し, 第 4 分劃投与 群は 124 (Counts/min.) と約 2 倍で, 有意の差を 認め，第 4 分劃に TSH 活性のあるととを示して いる. 又同時に测定した解等丸内 $\mathrm{P}^{32}$ 摂取率の結 果からみてG活性は下欄のように第 5 分劃に相当 量と第 4 分劃に微量恝められた．併しその他の分 劃には TSH 活性も G活性も梕められてい.

第 2 図はこの結果を示す。

次いで脳下垂体剔出ラッデる使用して上記 7 分劃につき各分劃毎の STH 活性と ACTH 活性を検討し た. 即ち前者には Tibia test ${ }^{6) 7}$, 後者には Sayers-Mounson 変法静注法 ${ }^{8}$ を採用した。その結果は第 2 表, 第 4 表に示す.

STH 活性 (Tibia test) は第 3 表のように第 1 分劃と第 2 分劃に，いずれも微量認められる.
第 2 図 各分劃每の $\mathrm{TSH}$ とG活性検討

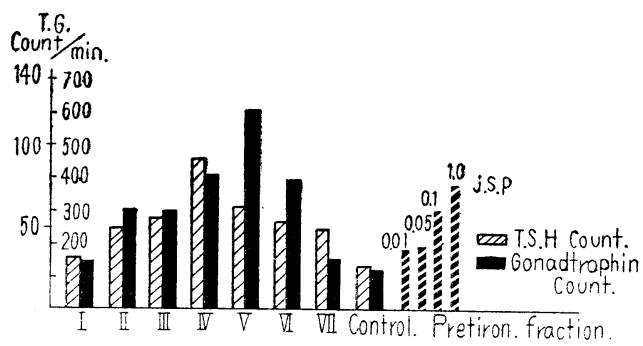


第3 表 各分劃毎の STH 活性檢討值

\begin{tabular}{|c|c|c|c|c|}
\hline fraction. & $\begin{array}{l}\text { sample } \\
\text { weight. }\end{array}$ & $\begin{array}{c}\text { No of } \\
\text { rats. }\end{array} \mid$ & $\begin{array}{c}\text { wide of Tibia } \\
(\mathrm{u})\end{array}$ & $\begin{array}{c}\text { potency } \\
\text { ratio }(\overline{\mathrm{u}} / \mathrm{mg})\end{array}$ \\
\hline 1 & 223.3 & 7 & $214.6 \pm 10.0$ & 0.0002 \\
\hline 2 & 277.7 & 7 & $221.2 \pm 7.5$ & 0.002 \\
\hline 3 & 173.7 & 4 & $196.7 \pm 8.5$ & none \\
\hline 4 & 140.9 & 6 & $189.1 \pm 3.2$ & " \\
\hline 5 & 353.9 & 6 & $190.2 \pm 5.7$ & " \\
\hline 6 & 379.2 & 9 & $194.1 \pm 6.6$ & " \\
\hline Control & - & 8 & $196.3 \pm 7.9$ & - \\
\hline \multicolumn{5}{|l|}{${ }^{*}$ standard } \\
\hline $0.3 \mathrm{mg}(0.42 \overline{\mathrm{u}})$ & - & 8 & $303.7 \pm 14.9$ & - \\
\hline $0.03 \mathrm{mg}(0.042 \overrightarrow{\mathrm{u}})$ & - & 8 & $231.2 \pm 17.6$ & - \\
\hline
\end{tabular}

Growth Hormone (Bovine) Armour Lab. Lot No. S92710 method: Tibia test 使用ラッテ数100匹

第 4 表は脳下垂体剔出ラッテ 160 匹を使用し Sayers-Mounson 変法静注法で ACTH 活性を検討した結果であるが，第 3 分劃に微量の活性が認められた.

\section{2）甲状腺刺戟ホルモン活性物質の分子量に関する検討}

上記の方法で分離精製した豚 TSH 活性物質は平面式濾紙電 気泳動法によつても単一な泳動像となる事が 確認できたが 0.1 $\mathrm{M} \mathrm{NaCl}$ 水で蛋白濃度 $0.8 \%$ となる様に溶解し，15分間隔で 80 分間，1分間 60000 回転で超遠心分離 ${ }^{9}{ }^{9 /}$ ) した処第 3 図に示す様 に，その沈降図形は単一な波形であつた，第 5 表はこの実験結

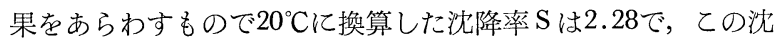
降図形から拡散系数を求めると Dは $1.23 \times 10^{-6}$ となる。従つて これらの数值から私の得た TSH 活性物質の分子量は19634で 大体20000前後と推察される.

\section{考按}

Loeb ${ }^{10)}$ 等により1929年下垂体前葉内に TSH の存在が発見さ れて以来, Junkmann \& Scheller $(1932)^{11)}$, Collip $(1935)^{12}$,

Frankel-Conrat $(1940)^{13)}$, Ciereszko $(1945)^{14)}$, Bates $(1959)^{15)}$, Bakke $(1960)^{16)}$ 等により各種動物の下垂体 及び体液から TSH の抽出並びに精製法が研究されているが TSH はGと同様な Glycoprotein Hormone でありながら，他の前葉ホルモン，特にGに比較して純粋に下垂体から取りだす事は今日尚困難である。

私は前報 ${ }^{17}$ 亿於いて市販されている TSH 製剂か電気泳動学的に 3 ケ乃至 4 ケの分劃に分離され，しかも 酸性溶液で泳動すると活性が減殺され，pH8.0附近では TSH の活性以外飞微量のG作用が介入する事も確 認した，又市販 TSH 製剂を使用して TSH の生物学的作用を検討するときは混在する他の tropic Hormone がその標的藏器を介して甲状腺に作用する可能性があり, 又反対に TSH による 2 次的反応の混在も当然子 想出来る。下垂体に含有される TSH は動物の種類によつて異なり，乙れ等を全く同一物質として取扱うこ とも危険である。従つて原料の明示されない市販製品による実験結果をそのまま承認することは適当でない， 故に単一原料から TSH 物質を抽出精製してその性状を検討すべきであると考え，豚脳下垂体前葉アセトン 粉末を材料として実験を行なつた.
第4表 各分劃毎の AGTH 活性検討值

\begin{tabular}{c|c|c}
\hline fraction. & $\begin{array}{c}\text { sample } \\
\text { weight. }\end{array}$ & $\begin{array}{c}\text { potency } \\
\text { ratio }(\mathrm{u} / \mathrm{mg})^{*}\end{array}$ \\
\hline 1 & 138.3 & 0.0002 \\
2 & 152.6 & 0.0002 \\
3 & 194.8 & 0.0040 \\
4 & 375.5 & 0.0002 \\
5 & 341.2 & 0.0002 \\
6 & 164.5 & 0.0003 \\
7 & 212.5 & 0.0001 \\
\hline
\end{tabular}

*USP Corticotropin Reference Standard (intravenous method)

method : Sayers-Mounson 変法静注法 使用ラッテ数160匹

第 3 図 超遠心分離法による 精製 TSH の沈降図形

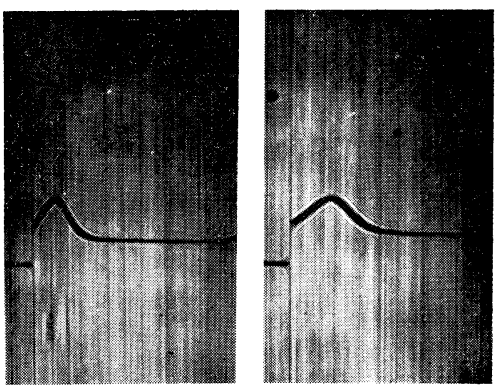

ultracentritugation of purified pig TSH. protein concentration $0.8 \%$ ; buffer : 0.1M NaCl-water pH7.0 6000r.p.m., pictures taken after 35 $\& 65$ minutes in a synthetic boundary cell $\mathrm{S}=2.3 \mathrm{~s} . \mathrm{D}=1.23 \times 10^{-6}$ molecular weight $19634 \fallingdotseq 20000$ 


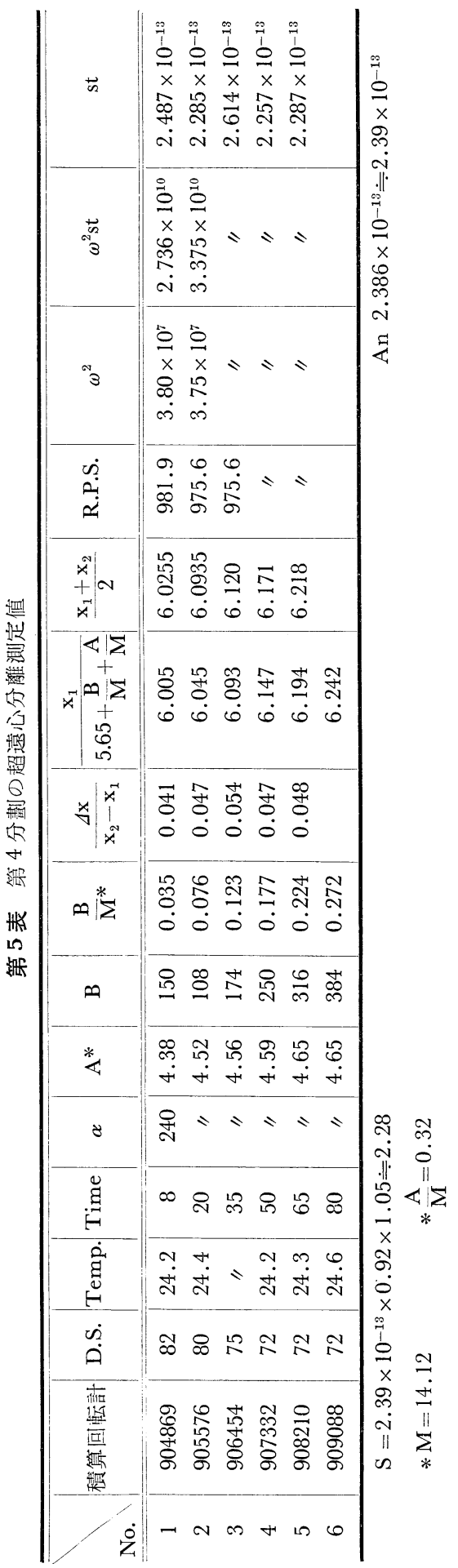

最近 Heidemann ${ }^{18)}$, P.G. Condliffe \& R.W. Bates ${ }^{19)}$ 等は牛 脳下垂体前葉を原料とし, 精製 TSH を採取し, その物理 化学的性状を検討する目的で IRC-50, Carboxylmethyl cellulose を用いた Golumn chromatography を採用して 比較的純度の高い TSH を得, 更にアルカリ性溶媒で使用 する Diethylaminoethyl-cellulose の Column chromatography で純度，活性の高い TSH を得た。

私は前報の連続式濾紙電気泳動法にもとずき豚下重体前 葉より TSH の分離精製を試みた。即ち第 1 罒は上記の条 件で下垂体前葉抽出液を泳動させたものであるが抽出液は 明暸に 7 ケに分劃されている。乙こに得られた 7 分劃に含 まれる TSH 活性とG活性は Greenspan 法と Florsheim 法 で同時に検したが，TSH 活性は第 4 分劃に，G活性は第 5 分劃に主として認められ，他に微量の $\mathrm{G}$ 作用を第 4 分劃 に認めた. 又との第 4 分劃の $\mathrm{TSH}$ 活性は $1 \mathrm{mg}$ 当り 15 20 J.S.U. であつた。 ての值は Bates 等の精製した TSH 活性能よりも稍々劣るが Bioassay の相違によるものと考 えられる。

豚脳下重体前葉アセトン粉末中には TSH 及びGの外に ACTH, STH, などの tropic Hormone の混入が一応子想 されるので Tibia test で STH を, Sayers-Mounson 変法 静注法で AGTH の検討を行なつたが TSH 活性を認め た第 4 分劃にはいずれの存在も認め得なかつた。第 3 表及 び第 4 表はてれを示している.

以上の結果から連続式滤紙電父泳動法によつても相当純 度の高い豚 TSH を得る事が出来, その精製分離に充分に 利用出来る事が判明した。

扱て TSH の物理化学的性状に関して Whitte $(1944)^{20)}$, Fels et al. $(1955)^{21)}$, は牛 TSH の沈降率, $1.0 \mathrm{~S}$ 分子量 10000, Pierce \& Carstan ${ }^{22}$ は Membrane 法で分子量既知 の蛋白と TSH の拡散率を比較して分子量は26000～30000 と推論している. Condliffe \& Bates $^{23}$ は彼等が牛脳下垂体 より精製した TSH そついてその沈降率は2.6S，分子量約 25000であり，組成アミノ酸, 糖についても報告している.

私の得た豚 TSHの分子量は日立超遠心分離器により検 討したが，その結果は第 3 図に図示されるように明瞭な蒴 一波形を示し，第 5 表から沈降率約 $2.3 \mathrm{~S}$ ，桩散系数は 1.23 $\times 10^{-6}$ となり, 算定 ${ }^{24)}$ 出来る分子量は約 20000 となる. $\mathrm{TSH}$ の沈降率，分子量は報告者によつて上記の如く若干異なる が，少なくとも私の得た数值から豚 TSH は沈降率2.3S， 分子量約 20000 の蛋白体であると結論出来る。 
結 論

1) 連続式濾紙電気泳動法により，豚下垂体前葉から精製 TSH を抽出分離し得た。

2）混入が予想される G, STH, AGTH, 活性物質の検討を行なつたが私の精製した豚 TSH には極めて 微量のG作用を認める以外には STH, ACTH 活性物質の存在は検出出来得なかつた.

3）精製豚 TSH の沈降率は2.3Sで，分子量は約20000であつた.

文献

1) 望月真人：日本内分泌学会雑誌, Vol. 36, No.4，668，1960. 2) Fels, I.G. and Simpson et al. : Biol. Ghem., $213: 311$ (1955). $\quad$ 3) Greespan, F.S., Kriss, J.P., Moses, L.E. and W. Lew : Endocrinology., $58: 767$ (1956). $\quad$ 4) Florsheim, W.H. : Acta. Endo., $30: 175$ (1959). $\quad 5)$ 田中明: ラ ッテ脳下垂体剔除法 (小山氏外聴道変法)，塩野義研究所年報，No.5，S. 35. $\quad 6$ ) Evans, H. M., M. E.

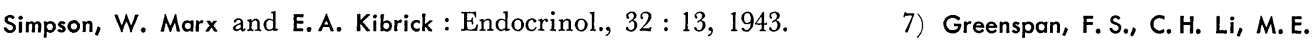
Simpson and H.M. Evans : Endocrinol., $45: 455$ (1949). $\quad$ 8) Munson, P.L., A.C. Barry and F.C. Koch : J. Clin. Endo., $8: 586,1948 . \quad 9)$ Bates, R.W. and P.G. Condliffe : Recentprogress in Hormone research., XVI, 308, $1960 . \quad 9$ 9) Williams, J.W. et al. : J.A.C.S., $74: 1542,1952 . \quad 10)$ Loeb, L. and R.B. Bassett : Proc. Soc. Exper. Biol. and Med., $26: 860,1929 . \quad 11)$ Junkmann, K. and W. Scheller : Klin. W. Schr., 11, 28, 1176, $1932 . \quad 12)$ Collip, J.B. et al. : J.A.M.A., 104 : $965,1935$.

13) Frankel-Conrat, H.J. et al. : J. Biol. Chem., $135: 199,1940 . \quad 14)$ Ciereszko, L.S. : J. Biol. Chem., $160: 585,1945 . \quad$ 15) Bates, R.W., M.M. Garrison and T.B. Howard : Endo., $65: 7,1959 . \quad 16)$ Bakke, J.L. : Am. Fed. for Clin. Res., $28: 106,1960.117)$ 望月真人：日本内分泌学会雑誌, Vol. 36, 4, 675, 1960. 18) Heideman, M.I.: Endocrinol., $53: 640,1953 . \quad 19)$ Condliffe, P.G. and R.W. Bates : J. Biochem., $23: 843,1956 . \quad 20)$ White, A. 1944. In "The Chemistry and Physiology of Hormones" (F.R. Moulton, ed.), P. 1. Association for the Advancement of Science, Washington, D.C. 21) Fels, I.G., M.E. Simpson and H.M. Evans : J. Biol. Chem., $213: 311,1955 . \quad 22)$ Pierce, J.G. and M.E. Carsten : J. A. G. S. $78: 751,1956$.

23) Bates, R.W. and P.C. Condliffe : Recentprogress in Hormone research., XVI, 345, 1960. 24）赤堀四郎, 水島三一郎 : 蛋白化学, 2,398 , 参照. 


\section{脳下垂体前葉ホルモンの濾紙電気泳動学的研究 及び分離抽出に関する研究}

第 5 報 豚脳下垂体性々腺刺戟ホルモンの分離精製並びに

下垂体性々腺刺戟ホルモンの生体内移行に就て

神戸医科大学産婦人科教室

大学院学生 望 月 真人

緒 言

前報々に於いて，連続式濾紙電気泳動法による甲状腺刺战ホルモンの分離精製を報じ，且つその分子量に 就いて発表を行なつたが，甲状腺刺㦸ホルモンと近い関係にある性腺刺㦸ホルモン（以下Gと略記）につい ても電気泳動学的研究を行なうとととした。

G TSH と同様糖蛋白 ${ }^{2}$ であると云われているが，その化学的性質は勿論その検定法や抽出法について はな㧍論議が多い。従つて私は連続式滤紙電気泳動法を利用し, 豚脳下垂体前葉から性腺刺㦸ホルモンの分 離精製を行なつた。

即ち下垂体性 Gの分離精製には使用する緩衝液はpH4.5の燐酸緩衝液とした。乙れは既報の TSH は塩基 性溶媒中でのみ安定であり，G酸性並びに塩基性溶媒中に於いてもその生物学的活性は安定であると云う 私の得た実験結果を利用したもので精製G特に LH 分劃中に TSH の混入を防ぐ意義を有している.

次に私は米国 National Institut of health (NIH) を介して頒布された $\mathrm{G}$ と私が連続式電気泳動法によつ て分離した豚下垂体性 $\mathrm{G}$ を電気泳動学的に比較検討を試みた。更に下垂体性 $\mathrm{G}$ の電気泳動学的知見に基づい てG活性物質の生体内移動の様相をも併せ追求した。

\section{実験材料並びに方法}

\section{1) 実験材料}

実験材料としては豚下垂体前葉アセトン粉末と Schering 社のAnteron を用いた。

$\mathrm{G}$ 活性検定には下垂体剔出㭃若ラッテと㭃若マウス ${ }^{3)}$ を使用した。

\section{2) 実験方法}

装置は既報のもので，緩衝液は Sörensen $\mathrm{Na}_{2} \mathrm{HPO}_{4}-\mathrm{KH}_{2} \mathrm{PO}_{4}$, イオン強度 $0.05, \mathrm{pH} 4.5$ で滤紙は No. 52 東洋濾紙, 泳動条件は $26 \mathrm{~mA} / 35 \mathrm{~cm}, 500 \mathrm{~V} / 40 \mathrm{~cm}$ で施行し, 染色法には Amidoblack 10B を用い, 透析に はビスキン膜を使用, 流水透析を行なう.

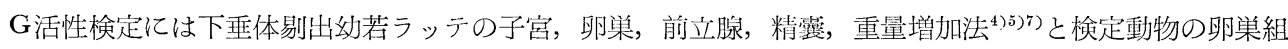
織像〕を併せ検討した。

\section{実 験 成 績}

\section{1）豚脳下垂体前葉アセトン粉末からGの分離精製について}

豚下垂体前葉アセトン粉末を $2 \%$ 食塩水で抽出した後, 遠心分離し, 得られた上澄液を装置内に垂直に 張つた濾紙の陽極側 $1 / 3$ の所に, 濾紙の毛細管現象在利用して少量宛たえず流し込む. ての様にして電気泳 動を行なうと第 1 図に示すように抽出液は 6 分劃に分離される.

それぞれの各分劃は前報に記載したように氷槽中に入れ，夫々強力に攪拌しつつ泠却 $99.5 \%$ エチールアル 第37巻 第 7 号 
第 1 図連続式濾紙電気泳動法による豚下 垂体抽出液の分離

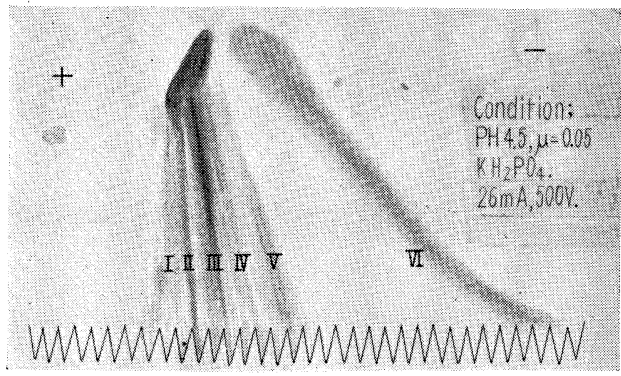

第 2 図 採取した下垂体性 $\mathrm{G}$

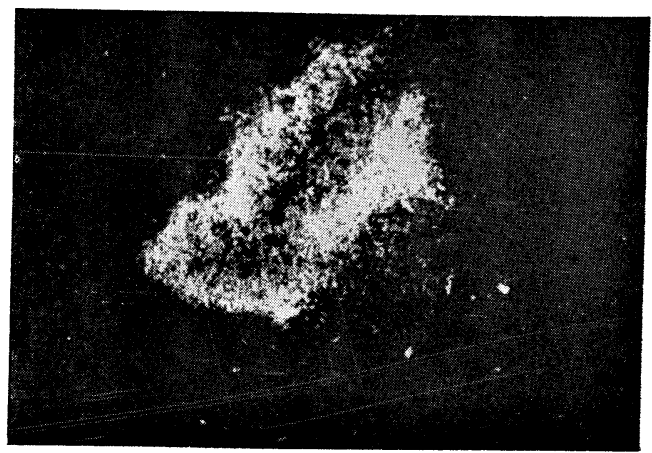

コールを $85 \%$ となるまで添加し，更に15時間冷蔵庫に静置保存する．以後遠心沈澱し得られた沈渣を再び再 生蒸溜水10ccに溶かした上，ビスキン膜を使用して72時間流水透析を行ない，再度ての溶液を前記の要領で 遠沈させ沈渣を10ccのエチールアルコール及びェチールエーテルで数回洗滌, 減圧真空乾燥してそれぞれの 6 分劃より白色結晶状物質》 を得る。第 2 図は得られた性腺刺㦸ホルモン活性物質を示す.

このようにして豚下垂体前葉より得られた 6 分劃物質を生後21日目から25日目の幼若ラッテ（雄，雌）で 下重体剔出した後，皮下に投与して検定動物の卵巣，子宮，前立腺，精囊，重量を測定して，その性腺刺㦸 作用を判定した。第 1 表はこの検定法の要領を示し，第 $2 ， 3$ 表はこの方法によつて判定した結果を示す.

\section{第 1 表 検定方法}

実験動物：生後21～25日目の幼若合, 古, ラッテ 実験方法：1) 下垂体剔出；1日

2 ) 注射; 第 8 日目第 9 日目加 開始 1 日 1 回, 3 日間皮下注

検定方法：第11日目に剖検

卵巣重量 $(\mathrm{R}+\mathrm{L}) \longrightarrow$ 組織検査

子宮重量

精囊重量

前立腺重量

第 3 表 検定各臓器重量

\begin{tabular}{c|c|c|c|c|c|c}
\hline Fraction & $\begin{array}{c}\text { B.W. } \\
(\mathbf{g})\end{array}$ & $\begin{array}{c}\text { Ovary } \\
\text { wt. } \\
(\mathrm{mg})\end{array}$ & $\begin{array}{c}\text { Uterus } \\
\text { wt. } \\
(\mathrm{mg})\end{array}$ & $\begin{array}{c}\text { B.W. } \\
(\mathrm{g})\end{array}$ & $\begin{array}{c}\text { S. } \\
\text { Vesicle } \\
(\mathrm{mg})\end{array}$ & $\begin{array}{c}\text { V. } \\
\text { prostata } \\
(\mathbf{m g})\end{array}$ \\
\hline \hline \multirow{2}{*}{1} & 27 & 9.4 & 14.0 & 39 & 2.5 & 4.8 \\
& 35.5 & 6.8 & 16.0 & 37 & 3.7 & 4.1 \\
\hline 2 & 45 & 22.3 & 64.0 & 51.5 & 8.5 & 7.5 \\
\hline 3 & 40 & 24.3 & 70.5 & 48 & 5.3 & 5.6 \\
\hline 4 & 36 & 7.5 & 16.0 & 死 & 死 & 死 \\
\hline
\end{tabular}

第 2 表 各分劃毎の $\mathrm{G}$ 活性検定用量

\begin{tabular}{c|c|c|c}
\hline \hline \multirow{2}{*}{ 分劃 } & $\begin{array}{c}\text { Amount } \\
(\mathrm{mg})\end{array}$ & \multicolumn{2}{|c}{ Gonadotropin Assay } \\
\hline 1 & 43.4 & $5 \times 3^{*}$ & $5 \times 3^{*}$ \\
\hline 2 & 2.3 & $1 \times 1$ & $1 \times 1$ \\
3 & 7.9 & $3 \times 1$ & $3 \times 1$ \\
4 & 2.2 & $1 \times 1$ & $1 \times 1$ \\
5 & 36.2 & $5 \times 3$ & $5 \times 3$ \\
6 & 54.0 & $5 \times 3$ & $5 \times 3$ \\
\hline
\end{tabular}

* total dose $\times$ No. of rats $(\mathrm{mg})$

これによると下垂体剔出幼若雄雌 ラッテに全量 $1 \mathrm{mg} \sim 5 \mathrm{mg}$ を注射し た場合，連続式濾紙電気泳動により 分離された各分劃のうち第 2 分劃投 与群と第 3 分劃投与群のみが対照群 に比して卵巣, 子宮, 前立腺, 精靈 の重量が増加していることが認めら れ, 第 2 分劃投与群では卵巣及び子 宮重量が増加しているが同時に精囊, 前立腺共にその重量が 2 倍以上に増 加しており, 第 3 分劃投与群では卵 巣及び子宮重量は第 2 分劃投与群よ 


\begin{tabular}{c|l|r|l|l|l|l}
\hline \multirow{3}{*}{5} & 48 & 6.0 & 15.5 & 46 & 4.7 & 2.9 \\
& 43 & 7.3 & 15.1 & 46 & 5.4 & 2.8 \\
& 41 & 5.5 & 15.6 & 44 & 5.5 & 4.2 \\
\hline \multirow{2}{*}{6} & 45.5 & 6.6 & 15.0 & 42 & 4.4 & 5.0 \\
& 32 & 6.0 & 14.35 & 40 & 4.1 & 3.1 \\
\hline \multirow{5}{*}{ 対照群 } & 48 & 6.4 & 15.8 & 43 & 4.1 & 2.8 \\
& 45 & 8.1 & 14.0 & 52 & 5.0 & 2.6 \\
& 38 & 10.8 & 21.0 & 31 & 3.6 & 2.1 \\
& 40 & 5.7 & 16.4 & 48 & 4.0 & 4.5 \\
\hline
\end{tabular}

第 3 図 各分劃每の $\mathrm{G}$ 活性検討 (脳下垂体前葉抽出液)

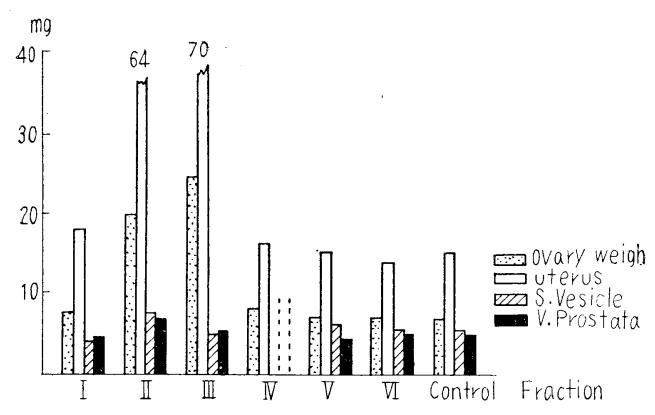

第ii図 第 2 分劃投与群

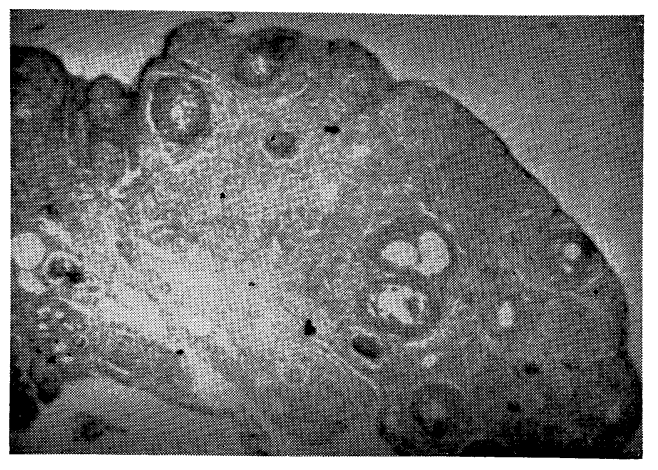

り著明に増加しているが，前立腺， 精孁の重量は余り増加していない. 即ち第 2 分劃には LH 作用が強く, 第 3 分劃は FSH 作用か強い.

第 3 図はとれを示す。

同時に検定に使用したラッテの卵 巣の組織所見は対照群（第 $\mathrm{i}$ 龱）に 比して第 2 分劃投与群は第i闵のよ うに間質の増殖が顕著であり，第 3 分劃投与群は第iii図のように卵胞の

第 $\mathbf{i}$ 図 対照群

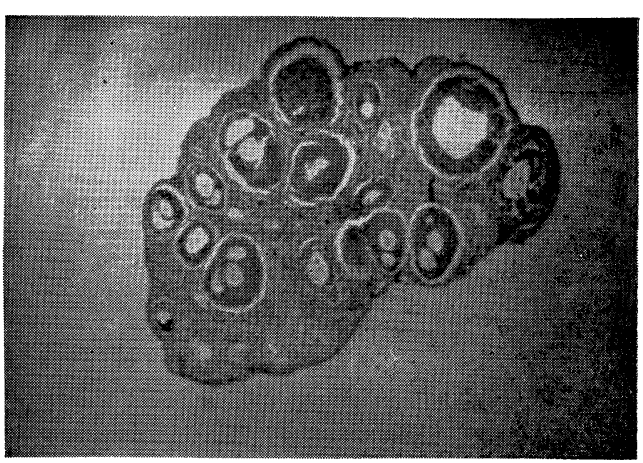

第 ii 図 第 3 分劃投与群

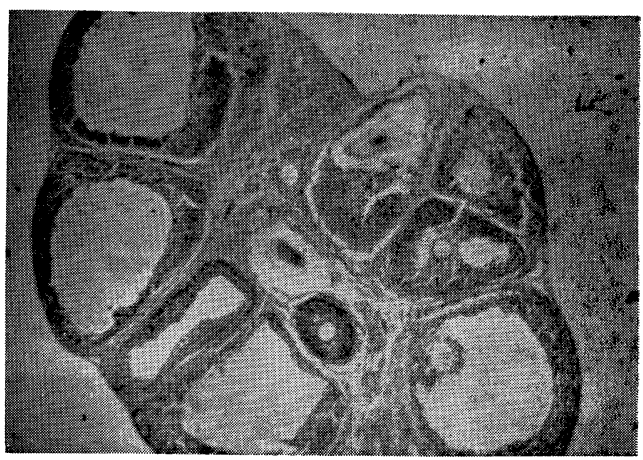

発育が著明である。従つて卵巣組織所見からも第 2 分劃には LH 作用が，第 3 分劃には FSH 作用が著明で あることが判明した。

\section{2) NiH より頒布されたGの電気泳動学的研究}

本品は米国 Emory 大学 A.E. Wilhelmi 教授がイオン交換樹脂カラムクロマトグラフィーを用い, 羊脳下 垂体前葉から分離精製したGでその内 FSH（NIH-FSH と略記）は250 で対照群の卵巣重量 2 倍值を示し， LH (NIH-LH と略記) は 0.4ugs で充分な卵巣充血がみられると記載している.

扱てての両者を上述同様な手技で濾紙電気泳動により分離した所第 4 図の様に酸性溶媒に於ける場合 NIH-FSH は陽極に 2 分劃に分離するが塩基性の場合には陽極に向う 1 分劃と陰極に向う 1 分劃とに分離さ れる. NIH-LH は FSH と異なり, 塩基性, 酸性いずれの溶媒でも常に陰極に向つて泳動し, ただ1つの 
第 4 図 NIH-FSH，NIH-LH の 水平式濾紙電気流動像

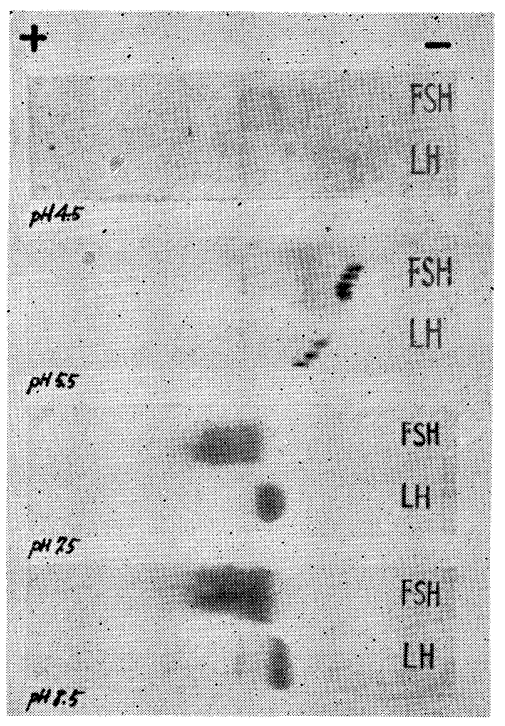

分劃のみを確認した。

\section{3） G活性物質の生体内移動に関する検討}

第 3 報に於いて TSH の生体内移動について報じたが，之に 準じて G活性物質の生体内移動の検討を行なつた。即ち下垂体 剔出幼若ラッテを使用し, 術後第 8 日目に下腿静脈から 50 単位 の Anteron を注射，20分後にラッテをエーテル麻酔し，開胸 してその心房内より全血を採取する. 1 分間 3000 回転で遠心沈 澱を行ない血清を分離し前述のような方法で連続式滤紙電気泳 動 $\left(17 \mathrm{~mA} / 30 \mathrm{~cm}, 420 \mathrm{~V} / 45 \mathrm{~cm}\right.$, pH8.5, Sörensen $\mathrm{KH}_{2} \mathrm{PO}_{4}-\mathrm{Na}_{2}$ $\mathrm{HPO}_{4}$, イオン強度0.05) を行なつて多量の血清分劃を得た. 得られた血清分劃を透析した後，アルコール濃度85\%にして遠 心沈澱を行ない, 得た沈渣をエチールアルコールで数回洗滌, 減圧真空乾燥を行なつて乾燥血清分劃を採取，その内に含まれ る $\mathrm{G}$ 活性を $8 \mathrm{~g}$ 前後の雌マウスを使用し子宮重量法で検討した. 第 4 表はこの結果を示す. 又第 5 図はこの成績を示したもので, 上欄はラッテ血清の ionogram である. 又下闌はその対応分劃 の $\mathrm{G}$ 活性を図示している. 即ち第 4 表及び第 5 図で明らかな如 く
第 4 表 血清分劃毎の $\mathrm{G}$ 活性測定值

\begin{tabular}{c|c|c|c|c|c}
\hline \hline 分劃 & $\gamma$ & $\beta$ & $\alpha$ & $\mathrm{Al}$ & 対照群 \\
\hline & 10.5 & 5.0 & 8.0 & 8.0 & 8.0 \\
子 & 11.5 & 9.5 & 7.5 & 7.5 & 6.0 \\
宮 & 10.5 & 8.0 & 6.0 & 8.0 & 5.5 \\
重 & 9.5 & 8.0 & 9.0 & 8.0 & 7.0 \\
(mg & 11.0 & 9.0 & 9.5 & 7.8 & \\
\hline
\end{tabular}

子宮重量増加を認め, 他の分劃投与群ではその重量増加を 認めない.

この事から G活性物質は生体内ではr-グロブリンと共に 移動すると考えられる.

\section{考按}

Zondek, B. $(1927,1928)^{9,10)}$, Smith, P.E. は未熟ラッテ に下垂体前葉組織を移殖し畉巣の卵胞が成熟することや黄 体化が惹起することを認め，下垂体中に性腺刺㦸作用の物
第 5 図 各血清分劃毎の $\mathrm{G}$ 活性検討世較

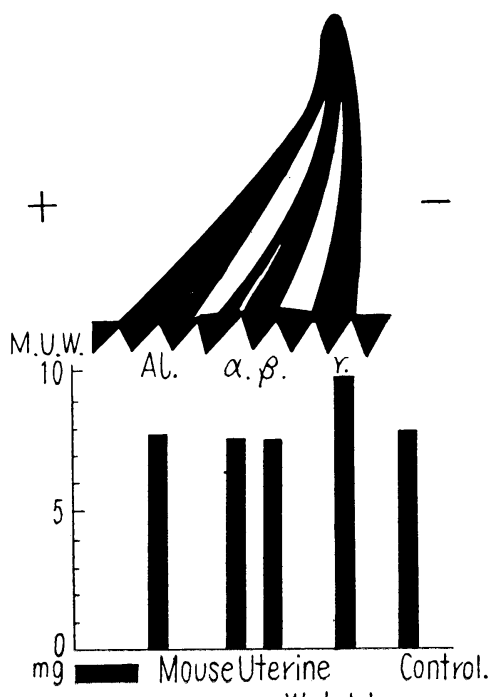

Weight.

質が存在することを知つた，又 Zondek はこの性腺刺㦸物質をその生物学的作用の点より prolan A, prolan

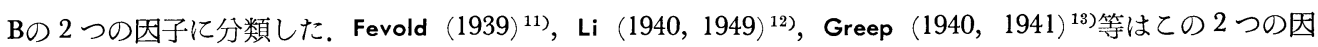
子を分離して卵胞刺㦸ホルモン $(\mathbf{F S H})$ と黄体形成ホルモン $(\mathbf{L H})$ とに区別した. てれらの業績は主として 動物実験によりその生物学的作用から下垂体性 Gの性状やその特性などを研究したものである.

近年蛋白質化学の進歩により，G自体の物理化学的性状が次第に明らかとなり，其の抽出法 ${ }^{14}{ }^{19}$ 並びに精 製法の研究20 24')が行なわれ，脳下垂体前葉から抽出されたG，殊に FSH，LH の化学的組成は動物によつ て著しい差異のあるととなどが明らかとなつた，又化学的に FSH と LH の両者を分離する試みは Crooke 
\& Butt $(1953,1954)^{25,26)}$ とよつて行なわれ Column chromatography の利用がなされた. 又 Brown (1955) ${ }^{27)}$ は脳下垂体 $\mathrm{G}$ と胎盤性 $\mathrm{G}$ と分離に Tricalcium phosphate の流体クロマトグラフィーを試みている.

私は既に下垂体前葉から proteo hormone の1つである TSH の分離精製に連続式濾紙電気泳動法を試 み TSHの結晶を得て物理化学的性状を明らかにした。そてで本法を応用して下垂体前葉中のGを連続式濾 紙電気泳動で分離精製を行ない FSH と LH の垂直濾紙上の移動差を検し，更に下垂体剔出幼若雄雌ラッテ を用い各分劃毎の生物学的作用の分析をも行なつた。第 1 図は下垂体前葉抽出液の分離像である。この6 分 劃毎の $\mathrm{G}$ 活性検定は第 1 表に示すような方法を行なつた．元来生物学的定量法はどのような方法によつても 使用動物による制約を受け随時に用い得ない難点があるが化学的定量法の不可能な現在では，これにたよる 他はない，従つて Gの生物学的検定法はその生物学的作用に基づき性腺に起る変化を利用するが，使用動物 の種類, 性別, 並びに性器又は副性器の利用法によつて極めて多種類の方法が発表されているが夫々一長一 短がある. 又 FSH と LH を個々に測定する場合，又 total G として検定する場合によつても何れの検定 法に拠るべきかは今日尚論議されている，従つて私は数多い検定法のうち第 1 表に示すような脳下垂体剔出 幼若雄雌ラッテを使用し，子宮，卵巣，精囊，前立腺重量増加による方法を採用し判定の正確を期した。第 3 表はこの結果であり第 2 分劃に LH 作用第 3 分劃に FSH 作用を示し, 検定動物の卵巣組織像でもこれと 一致した結果を示している。 又両者が略々 2 分劃に分離される事も判明した。 なお水平式滤紙電気泳動法で も FSH，LH は分離され FSH は LHよりも陰極に向つて良く泳動するが塩基性の場合 FSH は LH とは 異なり陽極に向つて泳動する分劃が出現する。

NIH-FSH と NIH-LH とを水平式滤紙電気泳動を行なつて検討した結果を上述したが，てれによつても NIH-FSH は NIH-LH よりも，よく泳動している。所が泳動距離は緩衝液によつて差があり，乙の FSH は緩衝液の $\mathrm{pH}$ によて左右されるが，LH はたえず一定の方向に移動し緩衝液の $\mathrm{pH}$ には影響されない.

扱ててのGが生体内で血液中のどの様な分劃に編入されて移行するかは常に密接な関係にある TSH 活性 物質の血中移動と比較して興味がある. Winzler $(1958)^{28}$ は人血清中の Muco 蛋白は $\alpha$-グロブリン分劃中の 構成々分であり，電気泳動的には $\alpha_{1}$ と $\alpha_{2}$ グロブリンとの中間に移動するが，Muco 蛋白だと云うGを平面

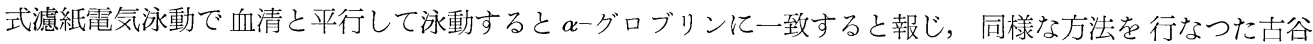
$(1960)^{29}$ も $\alpha^{-}$グロブリンの位置に $\mathrm{G}$ は移動すると報じた。 一方藤井 $(1960)^{30}$ は濾紙電気泳動で尿抽出 $\mathrm{G}$ 血清と平行に泳動させて $\beta$ グロブリンに相当する位置にGの Spot を得たと報告している. 最近 Nagy et al. $(1961)^{31)}$ は Durram (1950) の山形懸垂法を改良した方法で，妊娠中血清 HCG は $\beta$-グロブリン分劃と移動 するが過剩に HCG を血清中に与えた場合はrーグロブリン分劃にも Gの活性を認めると報告している.

この様に実験方法及び使用装置の差異によつて実験結果が異なることは問題を提起するが，(1)回じG剂で も動物の種属が違えば滤紙上の泳動像も異なるとと，(2)同じG作用を有しても FSH と LH との比率が異な るときは常に同じ泳動像を示すとは限らない事，の 2 点から電気泳動条件の異なる血清を同一滤紙上で $\mathrm{G}$ 平行的に泳動させても実験の確実性は期せないと考えられる。そこで私は外来的に Anteron を下垂体剔出 ラッテに静注し，その血清を連続法によつて多量に分離して $\gamma$ ーグロブリンの位置に明瞭なG活性作用の存在 することを認めたが， $\alpha ， \beta$ ーグロブリン分劃には G活性を認める事は出来なかつた。

\section{結 論}

1）豚脳下垂体前葉より連続式濾紙電気泳動法により略々 FSH と LH を分離出来た.

2) NIH-LH は濾紙電気泳動学的にみて，その純度が非常に高い.

3）生体中で下垂体性 $\mathrm{G}$ は常にrーグロブリンと共に移行している事を確認した.

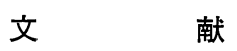

1）望月真人：本誌上第 4 報. $\quad$ 2) Li, C.H., M.E. Evans and P.H. Wonder : J. Gen. Physiol., $27: 737$, 1940. $\quad 3$ ) Lyon, R.A., M.E. Simpson and H.M. Evans : Endo., 53 : 674, 1953.

4) Loraine, J.A. 
: J. Endocr., 319, 1950.

5) Emmens, C.W. : L.N. Bull. Health Organiz., $8: 862,1939$.

6) Jensen, H., M.E. Simpson, S. Tolksdorf and H.M. Evans : J. Physiol., 79 : 180, 1933.

7) Evans, H.M. and M.E. Simpson: The Hormones (Ed. by G. Pincus and K. V. Thimann) Academic Press, New York. Vol. 2 : 351, 1950. 8) 大塚秀雄他 : J. Biol. Chem., Vol. 141, No. 5, 547, 1954.

9) Aschheim, S. and B. Zondek : Klin. Wochenschr., 6 : 1322, 1927.

10) Aschheim, S. and B. Zohdek : Klin. Wochenschr., $7: 1404,1928 . \quad 11)$ Fevold, H. L. : J. Biol. Chem., $128: 83,1939$. Endo., $24: 435$, 1939. 12) Li, C.H., M.E. Simpson and H.M. Evans: Science., $91: 530,1940 . \quad 13)$ Greep, R.O. et al. : J. Biol. Chem., $133: 289,1940$.

14) Bradbury, J.T., E.S. Brown and W.E. Brown : Proc. Soc. Exp. Biol. and Med., $71: 228,1949 . \quad 15)$ Bron, J.B. and J.A. Lorain : J. Endo., $13:$ ii (1956).

16) Gordman, A. : Endocrinol., $37: 177$ (1945). $\quad 17)$ Jugck, E.C., W.D. Maddock and C.C. Heller : J. Clin. Endo., $7: 1$ (1947). 18) Katzman, P.C. and E.A. Doisy : J. Biol. Chem., $98: 739$ (1934).

19) Levin, L. and H.H. Tyndale : Pro. Soc. Exper. Biol. and Med., $34: 516$ (1936). 20) Johnsen, S.G. : Acta. Endo., $20: 106$ (1955). $\quad 21)$ Albert, A., S. Kelly, L. Silver and J. Kobi : J. Glin. Endo. and Meta., $18: 600(1958)$ 22) Ringas, D.A., C.A. Panlsen and C.G. Heller : Endocrinol., $62: 738$ (1958). 23) Segaloff, A., S.L. Steelman, C. Evesett and A. Flores : Endocrinol., $62: 827,1957$.

24) Butt, W.R., A.C. Crooke and F.J. Cunnigham : Acta. Endo., $32: 509,1959 . \quad 24^{\prime}$ ) Woods, M.C. and M.E. Simpson : Endocrinol., 66, $4: 575$ (1960). $\quad 25)$ Crooke, A.C. and W.R. Butt : Proc. Soc. Study Fertility, $5: 87,1953 . \quad 26)$ Crooke, A.C., W.R. Butt and J.D. Ingram : Lancet., $1: 379,1954 . \quad 27)$ Brown, P.S. : J. Endocrinol., $13: 59,1955 . \quad 28)$ Winzler, R.J. : Chem. and Biol. of Mucopolysaccharide (1958). 29) 古谷博他：日杢不妊学会雑誌，5, No.7, 78, 1960. 30) 藤井久四郎他 ：産婦の世界，9，1451 (1957)。 31) Nagy, D., !. Gafi and G. Keller : Acta. Endo., 36 : 3, 438, 1961. 


\title{
脳下垂体前葉ホルモンの濾紙電気泳動学的研究 \\ 及び分離抽出に関する研究
}

\author{
第 6 報 人尿性々腺剌戟ホルモンの連続式汇紙電気泳動法 \\ による分離精製について \\ 神穴医科大学産婦人科教室 \\ 大学院学生 望 月 真 人 \\ 緒 \\ 言
}

尿中に排沮される $\mathrm{G}$ には 2 種類ある。その1つは下垂体前葉より分泌され，尿中にてれが排泄されたもの であつて，尿中の含有量はきわめて微量である。併しながら閉経期以後の婦人の尿中にはやや多く含まれて いる，以下てれを PMG と仮称する，穴の 2 は妊娠婦人尿中に含まれるGで胎船の䋐毛より産生されるも のであつて，その濃度はかなり高い，以下てれを HGG と略記する。

以上の 2 種類の $\mathrm{G}$ はそれぞれその産生蔵器である脳下垂体又胎盤から直接に抽出して得られる $\mathrm{G}$ との生 物学的性状, その他が多少相異すると云われている。 又動物の種属や産生臟器の別によつてもその諸性状が 若干異なると云われている。第 5 報て於いては豚下垂体前葉より連続式滤紙電気泳動法で, 下垂体性 $\mathrm{G}$ の分 離精製を試み，その性状について検討したが，今回は PMG 及び䋐毛性 G (以下 HCG と略記) の分離精 製を行ない，FSH と LH の夫々の単離を検討し，更に独逸 Köln 大学の Heinrichs 講師の分離精製した PMG（以下 Köln-G と略記）を濾紙電気泳動学的に検討を加え，更に連続式による方法で Köln-G の精製 を試みた。

\section{実験材料並びに方法}

\section{1) 実験材料}

実験材料としては妊娠前半期妊婦尿と後半期娃婦尿 並びに閉経期婦人尿を採取し應敗によるGの変性を防 ぐために採取した尿は出来るだけ速かに実験に供し た，止むを得ず保存する場合にはトルエンを上首に加 え, 水室に保存した。乙れは変性の速度は温度の上昇 と共に増加するからである。

\section{2) 実験方法}

\section{(1) 尿中よりGの抽出}

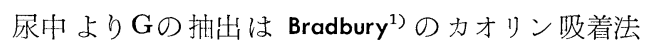
(1949) と Lorain ${ }^{2)}$, Albert ${ }^{2}$ )の改良法 (1956) を比較検 討し改良した松島の方法 ${ }^{4}$ によつた。 即ち10\%力オり ン吸着, $\mathrm{N}-\mathrm{NH}_{4} \mathrm{OH}$ で抽出した後, エタノール沈澱を 行ない, エタノール, エーテルで洗棌後, 減圧真空乾 燥を行なう。

以上の抽出法を表記すると第 1 表のようになる.

\section{（2）連続式濾紙電気泳動法}

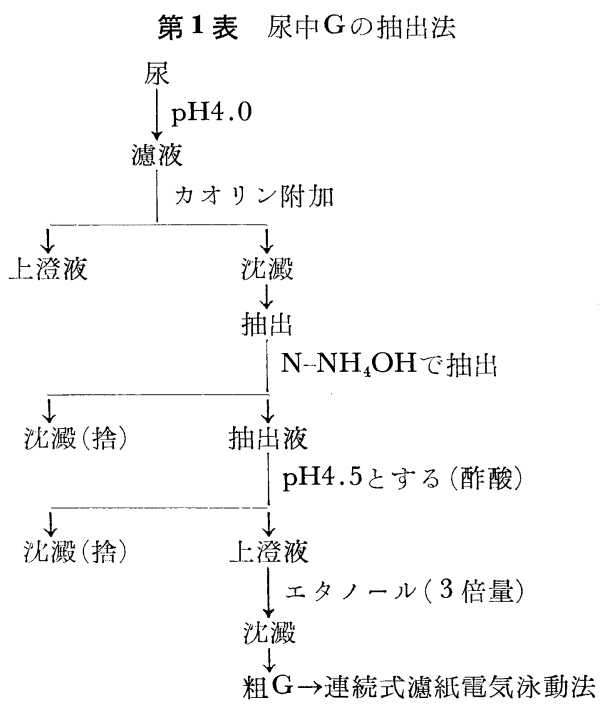


装置, 滤紙，緩衝液，泳動条件は第 5 報と同様，透析にはビスキン膜使用。

\section{(3) 検定動物}

脳下垂体剔出幼若雄雌ラッテを使用し，卵巣，子宮，前立腺，精垔重量增加測定のみならず，卵巣組織所 見をも検討した。

\section{3) 実験成績}

1. PMG の分離精製

前報で豚下垂体前葉アセトン粉末から下垂体性 $\mathrm{G}$ を分離精製した様に，粗 PMG 在所要の生理的食塩水に 溶解，試料を垂直に張つた滤紙の大体中央となる様に，滤紙の毛細管現象を利用してたえず少量宛流下，試 料がなくなるまで泳動を行なう。第 1 図は閉経期婦人尿より抽出した粗 $\mathrm{G} の$ 泳動像で，明らかに陰極側に移 動する 3 分劃を認める。

これらの各分劃から純白の精製 PMG を採取するのは前報と同じである。第 2 図は精製Gを示す.

各分劃毎の $\mathrm{G}$ 活性検定は生後21日目から 25 日目の下垂体剔出幼若ラッテを使用し, 検体を皮下に投与して 被検動物の卵宩，子宮，前立腺，精囊重量の増加を測定して判定した。第 2 表及び第 3 表はての結果を示す。

第 3 表によると被検動物に全量 $5 \mathrm{mg}$ を注射した場合，第 1 分劃投与群の及が対照群に比して卵巣，子宮， 前立腺, 精囊に重量增加が認められるが第 2 分劃投与群と第 3 分劃投与群は重量增加は認められなかつた。 従つて G活性は有しない，重量增加が認められる第 1 分劃投与群では卵巣, 子宮重量は対照群に比し著明な

第 1 図連続式滤紙霓気泳動法による PMG の分離

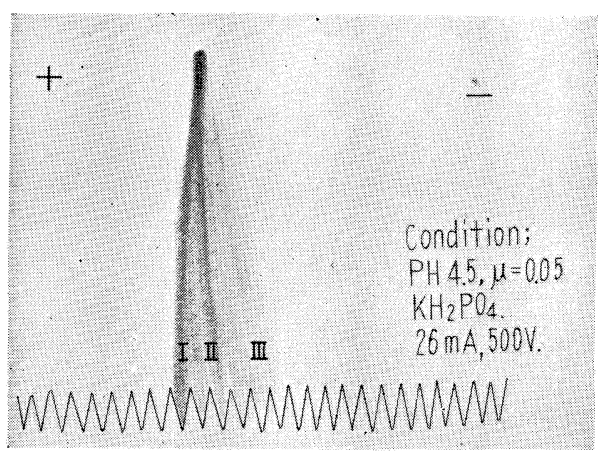

第2図採取した PMG

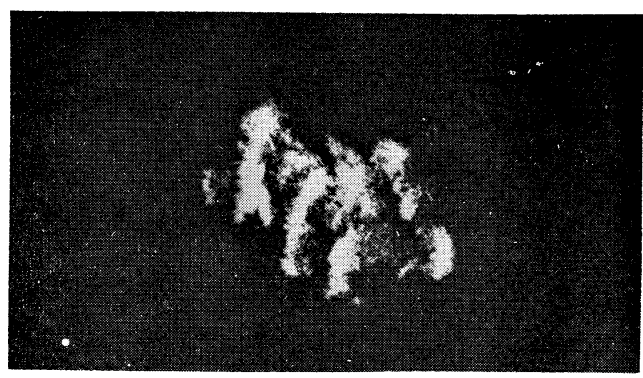

第 2 表 各分劃每の $\mathrm{G}$ 活㭠検定用量

\begin{tabular}{c|c|c|c}
\hline \multirow{2}{*}{ Fraction } & \multirow{2}{*}{$\begin{array}{c}\text { Amount } \\
(\mathrm{mg})\end{array}$} & \multicolumn{2}{|c}{$\begin{array}{c}\text { Gonadotropin } \\
\text { Assay }\end{array}$} \\
\cline { 3 - 4 } & & 早 & $\hat{\delta}$ \\
\hline 1 & 24.3 & $5 \times 2$ & $5 \times 2 *$ \\
2 & 18.3 & $5 \times 2$ & $5 \times 1$ \\
3 & 28.4 & $5 \times 2$ & $5 \times 2$ \\
\hline * total dose $\times$ No. of rats $(\mathrm{mg})$
\end{tabular}

増加を示さないが，前立腺重量は著明 に増加している。処が検定動物の卵单 所見は第 1 分劃投与群では対照群に比 して著明な卵胞の発育がみられ，間質
第3 表 各分劃每の G 活性測定值 (PMG)

\begin{tabular}{c|c|c|c|c|c|c}
\hline \hline Fraction & $\begin{array}{c}\text { B.W. } \\
(\mathrm{g})\end{array}$ & $\begin{array}{c}\text { Ovary } \\
\text { wt. } \\
(\mathrm{mg})\end{array}$ & $\begin{array}{c}\text { Uterus } \\
\text { wt. } \\
(\mathrm{mg})\end{array}$ & $\begin{array}{c}\text { B.W. } \\
(\mathrm{g})\end{array}$ & $\begin{array}{c}\text { S. } \\
\text { Vesicle } \\
(\mathrm{mg})\end{array}$ & $\begin{array}{c}\text { V. } \\
\text { prostata } \\
(\mathrm{mg})\end{array}$ \\
\hline \multirow{2}{*}{1} & 46 & 7.3 & 15.3 & 48 & 5.7 & 13.6 \\
& 42 & 10.5 & 18.0 & $\zeta$ & $\zeta$ & $/$ \\
\hline \multirow{2}{*}{2} & 40 & 6.9 & 13.1 & 38 & 4.5 & 3.2 \\
& 35 & 5.8 & 14.1 & & & \\
\hline \multirow{2}{*}{3} & 47 & 6.1 & 16.4 & 35 & 4.2 & 2.7 \\
& 42 & 7.4 & 13.3 & 45 & 5.3 & 6.9 \\
\hline \multirow{3}{*}{ 対照群 } & 48 & 6.4 & 15.8 & 43 & 4.1 & 2.8 \\
& 45 & 8.1 & 14.0 & 31 & 5.0 & 2.6 \\
& 40 & 5.7 & 16.4 & 48 & 4.0 & 4.5 \\
\hline
\end{tabular}

第37巻 第 7 号 
第 3 図 対照群の畉巣組織像

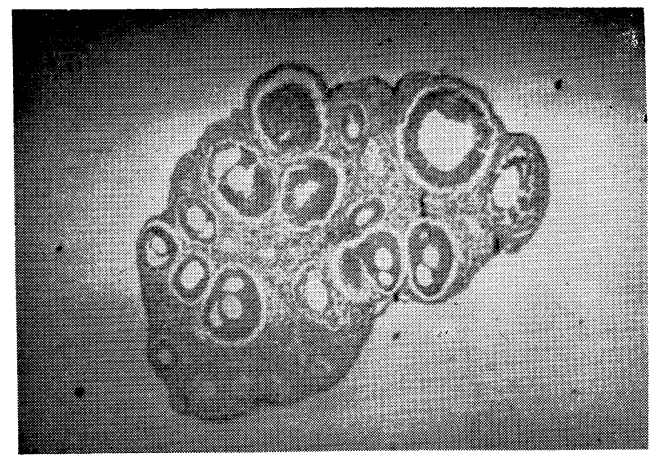

第 4 表 各分劃投与群の卵巣 組織像の比較

\begin{tabular}{c|c|c}
\hline \hline 分劃 & 卵胞肥犬 & $\begin{array}{c}\text { 間質壃殖 } \\
\text { (黄体形成) }\end{array}$ \\
\hline \hline 対照群 & - & - \\
1 & H & + \\
2 & - & - \\
3 & - & - \\
\hline
\end{tabular}

の増殖は著明でない，

第 3 図（対照群卵宩所見）と第 4 図はてれを示 す.

第 4 表は各分劃の被検動物の卵巣組織所見を示したものであり，第 5 四は第 3 表の結果を図示したもので ある.

2. HCG (妊娠前半期) の分離精製

娃娠前半期弤婦尿から抽出した粗 HCG 在上記と同様な方法で分離精製すると第 6 図のように 4 分劃に分 離される。

この各分劃から精製Gを採取するのは上記の通りで，第７図は得られた純白の精製 $\mathrm{G}$ 示す。

この分劃每のG活性検定は既述と同様検定方法で，被検動物の卵巣組織所見を併せ検討するのも同様であ

第 6 図＼cjkstart連続式濾紙電気泳動法に上る HCG（前半期）の分離

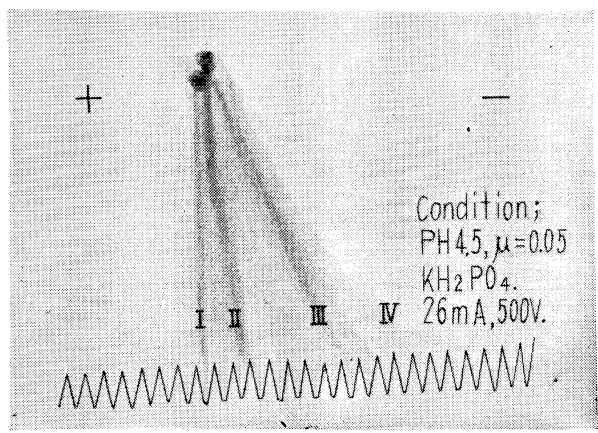

第 4 図 第 1 分劃投与群の卵栄組織像

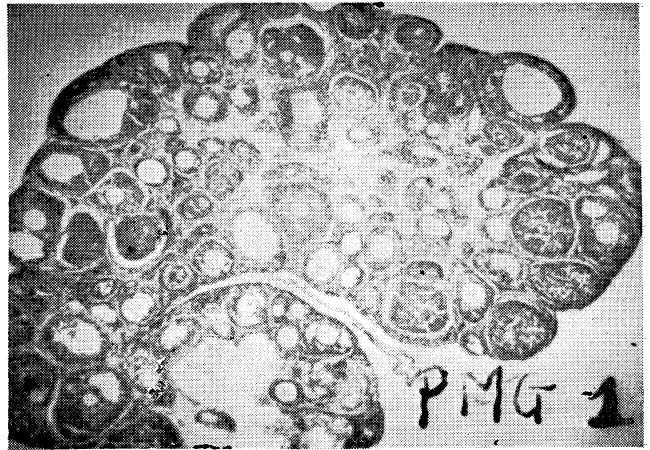

第5 図 各分劃每の $\mathrm{G}$ 活性検討 $(\mathrm{PMG})$

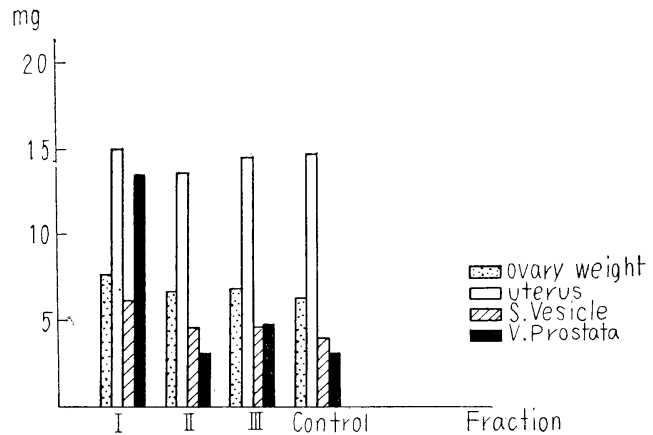


第 5 表 各分劃毎の $\mathrm{G}$ 活性検定用量

\begin{tabular}{c|c|c|c}
\hline \hline \multirow{2}{*}{ Fraction } & $\begin{array}{c}\text { Amount } \\
(\mathrm{mg})\end{array}$ & \multicolumn{2}{|c}{$\begin{array}{c}\text { Gonadotropin } \\
\text { Assay }\end{array}$} \\
\cline { 3 - 4 } & & ㅇ & 令 \\
\hline \hline 1 & 71.8 & $5 \times 3$ & $5 \times 3 *$ \\
2 & 10.9 & $5 \times 1$ & $5 \times 1$ \\
3 & 14.1 & $5 \times 1$ & $5 \times 1$ \\
4 & 43.9 & $5 \times 3$ & $5 \times 3$ \\
\hline
\end{tabular}

* total dose $\times$ No. of rats $(\mathrm{mg})$

る.

その結果は第 5 表と第 6 表に示す.

即ち第 6 表によれば各分劃每に下垂体 剔出幼若ラッテを使用し，皮下に全量 $5 \mathrm{mg}$ を投与した場合，妊娠前半期 HCG の 4 分劃のうち第 1 分劃投与群

と第 2 分劃投与群のみが対照群に比較して卵巣子宮, 精孁, 前立腺の重量の増加を認める. 併し第 1 分劃投 与群は精覀, 前立腺重量の増加より卵巣重量の増加が 著明であり，一方てれに反して第 2 分劃投与群は前立 腺, 精囊重量增加が著明である。

第 8 図はこの結果を図示するものである.

被検動物に使用した下垂体剔出幼若ラッテの卵巣組 織所見は第 3 図の対照群に比して第 1 分劃投与群第 9 図は卵胞の発育が強く, 第 2 分劃投与群第 10 図は間質 の肥大がみられる。

3. HCG（妊娠後半期妊婦尿）の分離精製

妊娠前半期の場合と全く同様な方法で分離すると第 11 図のように妊娠前半期粗 HCG と異なり 3 分劃に分 離される。

第 9 図第 1 分劃投与群の卵巣組織像

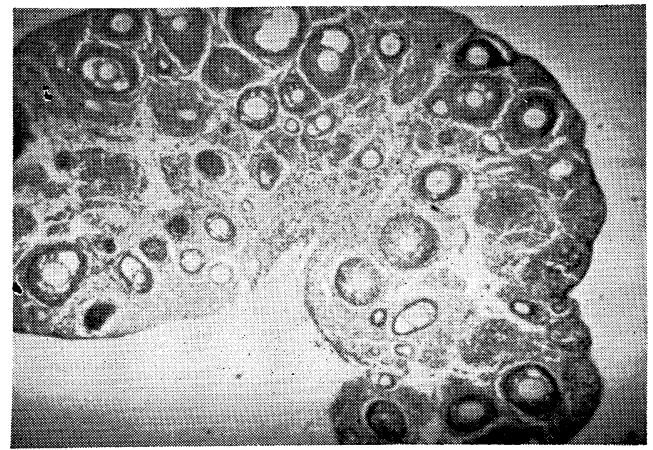

第 8 図各分劃毎の $\mathrm{G}$ 活性検討 ( $\mathrm{HCG}$ 前半期)

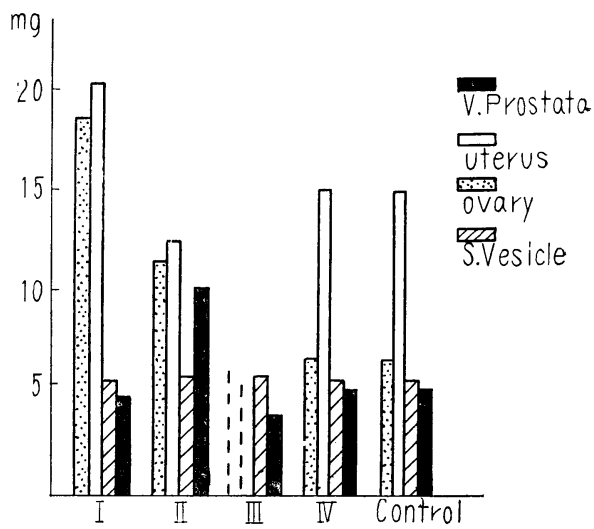

第10図 第 2 分劃投与群の卵巣組織像

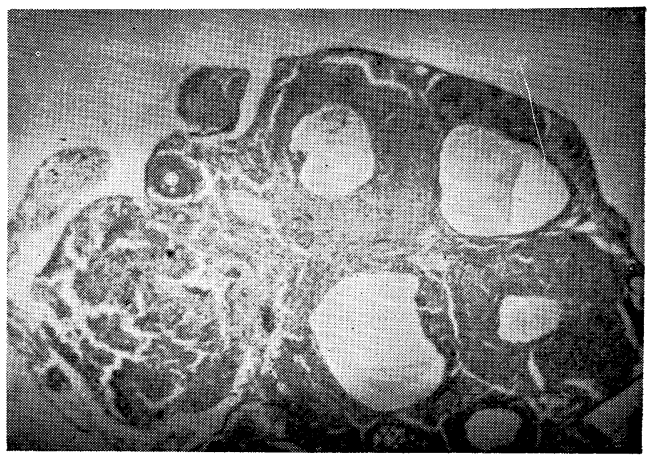


第11図＼cjkstart連続式滤紙電気泳動法による

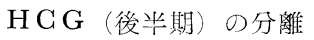

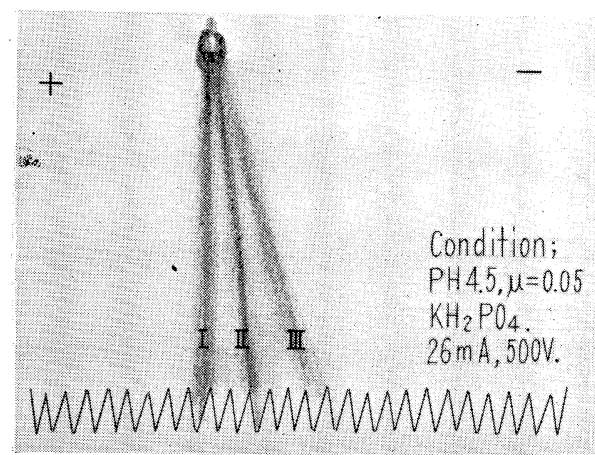

第12図 採取した HCG（後半期）

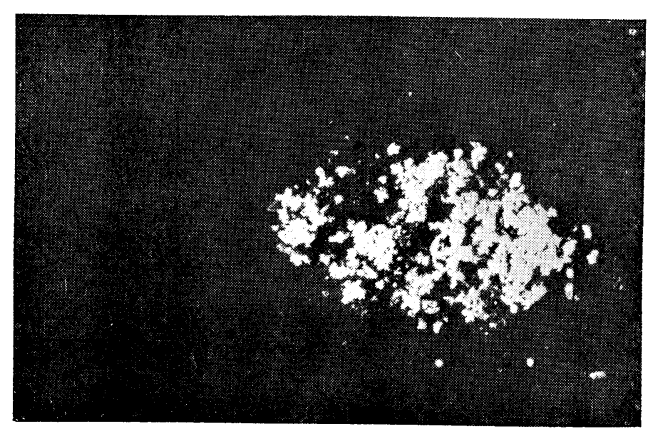

これらの各分劃から得た精製 $\mathrm{G}$ は第 12罒のように純白の結晶状を示すが妊 娠前半期 HCG と比較すれば妊娠後半 期 HCG の方が微細な結晶状を示して いる。乙の精製分劃毎のGの活性検討 の結果は第 7 表と第 8 表に示される. 即ち第 8 表によれば第 1 分劃と第 2

第 7 表 各分劃毎の $\mathrm{G}$ 活性検定用量

\begin{tabular}{|c|c|c|c|}
\hline \multirow{2}{*}{ Fraction } & \multirow{2}{*}{$\underset{(\mathrm{mg})}{\text { Amount }}$} & \multicolumn{2}{|c|}{$\begin{array}{c}\text { Gonadotropin } \\
\text { Assay }\end{array}$} \\
\hline & & 우 & $\hat{\jmath}$ \\
\hline 1 & 75.2 & $5 \times 3$ & $5 \times 3 *$ \\
\hline 2 & 39.4 & $5 \times 3$ & $5 \times 3$ \\
\hline 3 & 34.6 & $5 \times 3$ & $5 \times 3$ \\
\hline
\end{tabular}

* total dose $\times$ No. of rats $(\mathrm{mg})$

第13図 各分劃毎の $G$ 活性検討 ( $\mathrm{H} \mathrm{G} \mathrm{G}$ 後半期)

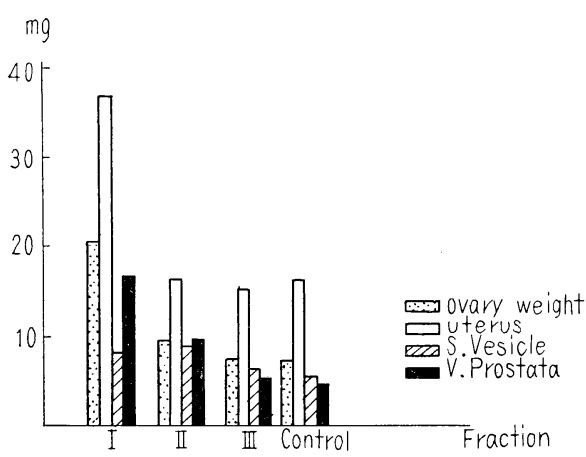

第 8 表 各分劃毎の $\mathrm{G}$ 活性測定值 ( $\mathrm{H} \mathrm{G} \mathrm{G}$ 後半期)

\begin{tabular}{|c|c|c|c|c|c|c|}
\hline Fraction & $\begin{array}{l}\text { B.W. } \\
(\mathrm{g})\end{array}$ & $\begin{array}{c}\text { Ovary } \\
\text { wt. } \\
\text { (mg) }\end{array}$ & $\begin{array}{c}\text { Uterus } \\
\text { wt. } \\
\text { (mg) }\end{array}$ & $\begin{array}{l}\text { B.W. } \\
(\mathrm{g})\end{array}$ & $\begin{array}{c}\text { S. } \\
\text { Vesicle } \\
\text { (mg) }\end{array}$ & $\begin{array}{c}\text { V. } \\
\text { prostata } \\
(\mathrm{mg})\end{array}$ \\
\hline \multirow{3}{*}{1} & 46 & 20.8 & 24.5 & 46 & 9.1 & 23.7 \\
\hline & 26 & 22.0 & 48.9 & 48 & 6.5 & 8.8 \\
\hline & / & / & $\zeta$ & 48 & 5.9 & 13.9 \\
\hline \multirow{3}{*}{2} & 39 & 9.6 & 15.5 & 42 & 7.5 & 10.1 \\
\hline & 44 & 8.4 & 15.9 & 40 & 8.5 & 12.0 \\
\hline & 39 & 12.3 & 17.0 & ノ & $\zeta$ & $\zeta$ \\
\hline \multirow{3}{*}{3} & 39 & 8.3 & 15.4 & 54 & 5.3 & 6.1 \\
\hline & 37 & 5.0 & 12.4 & 46 & 5.9 & 4.2 \\
\hline & 47 & 7.9 & 14.9 & 39 & 3.8 & 3.1 \\
\hline \multirow{3}{*}{ 対照群 } & 48 & 6.4 & 15.8 & 43 & 4.1 & 2.8 \\
\hline & 45 & 8.1 & 14.0 & 31 & 5.0 & 2.6 \\
\hline & 40 & 5.7 & 16.4 & 48 & 4.0 & 4.5 \\
\hline
\end{tabular}

第14図 第 1 分劃投与群の卵巣組織像 ( $\mathrm{H} \mathrm{G} \mathrm{G}$ 後半期)

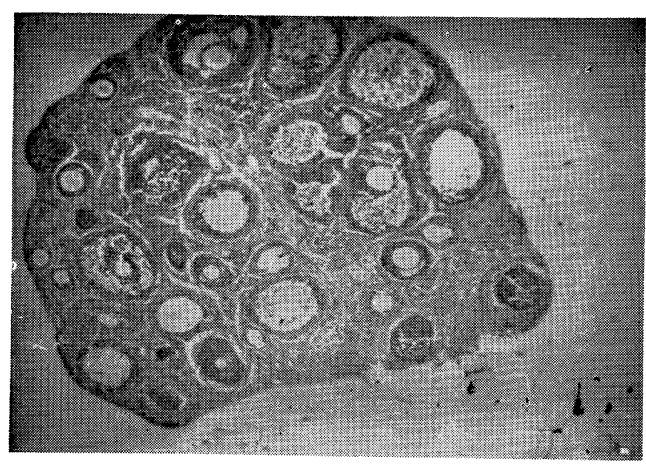


分劃に $\mathrm{G}$ 活性を認める。第 1 分劃投与群は卵巣，子宮は刘照群の 2 倍以上の重量増加があり，精囊，前立腺 もいずれもその重量が増加している. 第 2 分劃投与群は対照群に比較して卵巣, 子宮共に余り重量の増加を 認めないが，精麗，前立腺共汇著明な重量の增加を認める。

第13図はこの結果を図示したものである。

又卵巣組織所見は第 1 分劃投与群（第14図）では卵胞，間質ともに肥大しているが，特に卵胞の発育が著 しい. 第 2 分劃投与群（第15図）では間質の増殖が著明である。

第15図 第 2 分劃投与群の卵巣䋎織像 ( $\mathrm{H} \mathrm{G} \mathrm{G}$ 後半期)

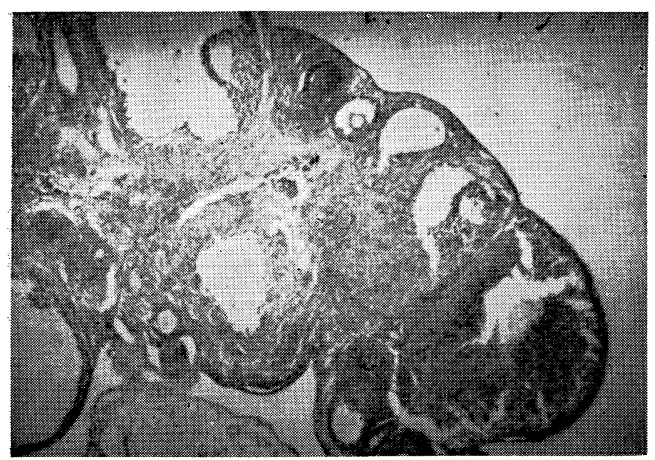

第 9 表 各分劃每投与群の 卵栄組織像の比較

\begin{tabular}{|c|c|c|}
\hline 分劃 & 卵胞肥犬 & $\begin{array}{l}\text { 䦔質増殖 } \\
\text { (黄体形成) }\end{array}$ \\
\hline 1 & HWH & + \\
\hline 2 & + & $H$ \\
\hline 3 & - & - \\
\hline 4 & - & - \\
\hline 1 & HI & + \\
\hline 2 & $\div$ & HH \\
\hline 3 & - & - \\
\hline
\end{tabular}

以上両者の結果をまとめると第 9 表のようになり第 1 分劃投与群ではいずれも FSH 効果が強く, 第 2 分 劃投与群では LH 効果が強い事を認める。

4. Köln-G の濾紙電気泳動学的検討

本品は Köln 大学産婦人科教室 Heinrichs 講師が閉経期婦人尿よりカオリン吸着法で抽出, アセトン法に よつて精製したものである。その力価を吾々の教室の安水，玉岡が検定した所 $1 \mathrm{mg} 1$ 単位以下であつた.

この Köln-G を酸性及び塩基性溶媒で水平式濾紙電気泳動（条件；6 mA $/ 10 \mathrm{~cm} ， 400 \sim 280 \mathrm{~V} / 40 \mathrm{~cm}$, $8 \sim 9$ 時間）したものは第16図に示される様に酸性溶媒では陰極側に 2 〜分劃，又塩基性溶媒でに下図の 様に陽極側に 2 分劃に分れて泳動している.

次でこの Köln-G を連続式濾紙電気泳動を行なうと第17図 $\mathrm{pH} 4.5$ で分離精製した様に水平式の場合より

第16図 水平式滤紙電気泳動法による Köln-G の泳動像

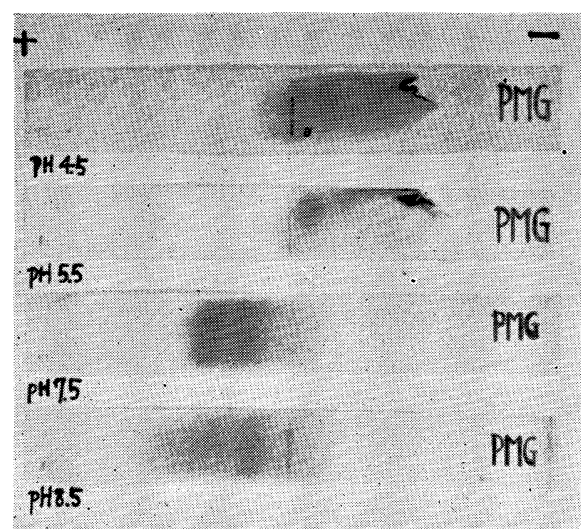

更に多くの5 分劃に分離されている.

第18図は同じく $\mathrm{pH}$ 8.5で Köln-G を連続式滤紙 電気泳動を行なつたものであるが第17図酸性の場合

第17図 酸性溶媒に於ける Köln-G の 連続式濾紙電気泳動像

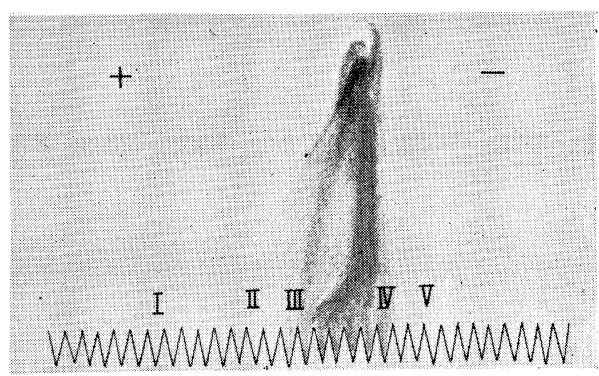


第18図 塩基性溶媒に於ける Köln-G の 連続式濾紙電気泳動像

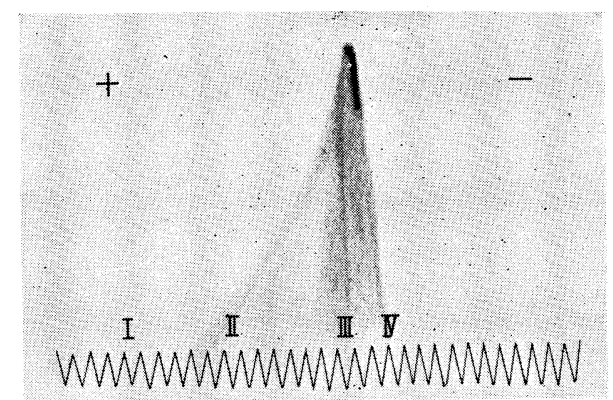

第19図＼cjkstart各分劃毎の $\mathrm{G}$ 活性検討

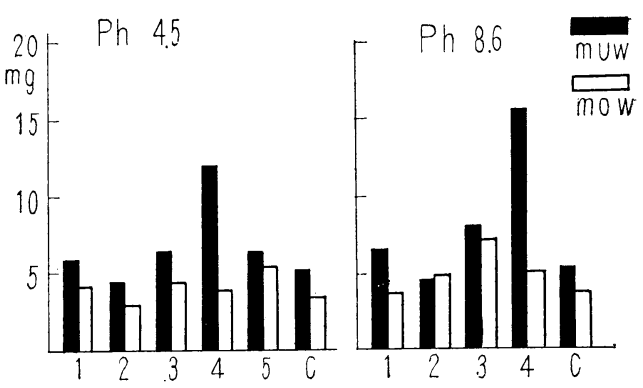

と同様水平式よりも 2 分劃多い 4 分劃に分離されている.

扱てての各分劃毎の生物学的活性をマウス卵宩子宮重量法で検討した.

第19図はこの検討結果であつて，酸性では第 4 分劃投与群に子宮重量増加と第 5 分劃投与群に卵巣重量増 加を認めるが，塩基性では第 3 分劃投与群に卵单重量増加と若干の子宮重量増加を，第 4 分劃投与群に著明 な子宮重量増加と若干の卵巣重量の増加があり, 塩基性, 酸性, 溶媒いずれに於いても2 ツの分劃にG活性 を認めるが FSH 作用と LH 作用は完全には分離されていない.

考按

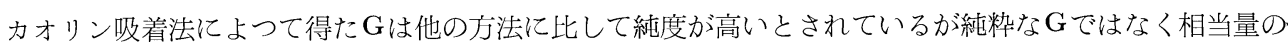
不純物を含んでいる。

しかしながら脳下垂体からのGについては FSH と LH とに夫々別個の独立した物質として分離され，又 その物理化学的性状も近年明らかにされているが，既述の人尿性Gでは HCG は勿論の事 PMG に於いて も FSH と LH 両作用が認められているにも拘らず今日ではまだ両者を完全に分離するととに成功していな い. 従つて尿中の FSH と LH は動物の下垂体から抽出された FSH と LH と同様に独立しているものか, 或は一物質の 2 作用と考えるべきであるかは全く不明である.

最近 Johnsen $(1955)^{5)}$ ，Albert $(1958)^{6)}$, Ringas $(1958)^{7)}$, Segaloff $(1959)^{8)}$ は種々の方法を採用して，乙 の問題を研究している. 特に Segaloff は電気泳動, 超遠心分離, その他の分析方法によつて純粋と思われ るGの分離に成功した。しかしこの純粋と云われる Gは強い FSH 作用を示したが同時に LH の作用も有し， しかもこの他に LH 分劃を得，乙れは化学的に純粋ではなかつたが FSH 作用を有していなかつたと報告し ている，又他の学者も夫々相当に高い純度のGを分離しているが $\mathrm{FSH}$ とH との分離には成功していない。

Crooke $(1959)^{9}$ は最近イオン交換樹脂を用いる分離法を試みているが FSH と LH との分離は完全でない. 私は前報で詳述したように連続式滤紙電気泳動法を利用し，カオリン吸着法によつて抽出した粗Gの分離

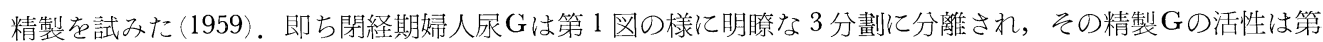
1 分劃のみに陽性である。しかし強い FSH 作用を示すと同時に若干の LH 作用も有している.

又第 6 図，第 11 図は妊婦尿粗 $\mathrm{G}$ の泳動像であるが妊娠前半期尿 $\mathrm{G}$ では 4 分劃に，妊娠後半期尿 $\mathrm{G} 3$ 分劃 に分離されているが両者とも第 1 分劃と第 2 分劃にその生物学的活性を有している. 即ち第 1 分劃に主とし て FSH，第 2 分劃に主として LH 作用のある事を実証したが FSH 活性を認めた第 1 分劃に若干の LH 活 性を検出した。 又卵巣組織所見からみると FSH 作用は妊娠前半期尿 Gの方が強く, LH 作用は後半期尿 G の方が優位である。

此の様に妊娠初期尿 Gに FSH 作用が強いのは此時期では下垂体性Gの混在しているてとを思わせるもの であり，更に妊娠初期には粗Gが 4 分劃に分離されて泳動することは HCG の他に FSH 作用のある物質を 含んでいると考えられる。 ての事は赤須 $(1958)^{10)}$, Lyon $(1953)^{11)}$ も報告している. 
次に Köln-大学産婦人科教空 Heinrichs 請師が閉経期婦人尿中より 精製した Köln-G を濾紙電気泳動学 的に検討したが滤紙電気泳動学的にみて純度が低かつた。この Köln-G を連続式濾紙電気泳動で分離した 所いくつかの分劃に分れたが，そのうち中央に近い２分劃に生物学的活性を認めたが，両者にはＦSH 作用 と LH 作用が混在していた.

以上更年期婦人尿，妊娠前半期並びに後半期弤婦尿及び Köln-G について行なつた実験や文献からみて

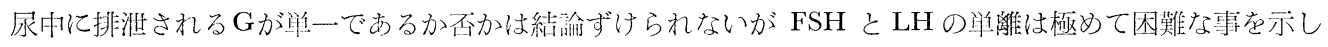
ている.

次に Segaloff $(1955)^{12}$ は PMG は1つの蛋白質に低分子の FSH, LH 作用部分が結合して 1 分子を形成 するものとすれば両者の分離は不可能であり，闭者の結合の比率が変り得るものとすればその結合の比率が 異なることにより作用が異なるものと推起している. Brown (1959) ${ }^{12}$ も此の考え方に同意し, 両者の比率の 差によつて作用が異なるものであると述べているが，一方て机に刘して Lorain $(1958)^{14)}$ は FSH と LH は 別個のものであるとしている.

いずれにしても PMG，HCG はPGに比して FSH とLHの分離は困蜼であり，化学的な而でも今後更 に検討すべき多くの间題在含む.

綰 論

連続式濾紙電気泳動法により尿㠹Gの分離精製を侙みた。

1) 閉経期婦人尿 Gは 3 分劃に分れ, 第 1 分劃にのみ G活性を有するが強い FSH 作用の他に若下の LH 作用を含す。

2) 妊娠前半期妊㖊尿 $\mathrm{G}$ は 4 分劃に分れ, 符 1 分劃と節 2 分劃に生物学的活性を有する. 即ち第 1 分劃に は FSH 作用漒く, 第 2 分劃は LH 作用か漒い.

3) 妊娠後半期妊婦尿 $\mathrm{G}$ は 3 分劃に分れ, 第 1 分劃と第 2 分劃とに $\mathrm{G}$ 活性を有する。即ち第 1 分劃はFSH 作用か漒く, 第 2 分劃は LH 作用か漒い.

4) 妊娠前半期弤婦尿 Gの方が後半期尿 Gr比して FSH 作用が強い.

5） Köln-G を連続式滤紙電気泳動法で精製したが FSH とLH を完全に分離する事は桠来なかつた.

\section{文献}

1) Bradbury, J.T., E.S. Brown and E.W. Brown : Proc. Soc. Exper. Biol. and Med., 71 : 228, 1947.

Lorain, J.A. and J.B. Brown : J. Clin. Endo., $16: 1180,1956 . \quad 3)$ Albert, A. : Recentprogress in Hormone Research., $12: 227$ (1956). $\quad 4)$ 松島早苗：皮虞と必尿，20:225，1958. 5)，6)，7), 8)，9）：本誌，第 5 報，文献参照. 10）赤須文男：胎盤の内分泌，南江堂，1958. 11) Lyon， R.A., M.E. Simpson and H.M. Evans : Endocrinol., $53: 674,1953 . \quad 12)$ Segaloff, A.: Year Book of Endocrinol., 266, 1954 1955.

13) Brown, P.S. : J. Endocrinol., $18: 46,1959$.

14) Loraine,

J.A., J.S. Brown and A. Klopper : J. Endocrinol., $17: 401,1958$. 


\title{
脳下垂体前葉ホルモンの濾紙電気泳動学的研究
}

\section{及び分離抽出に関する研究}

\author{
第 7 報 総括; TSH 活性物質とG活性物質の関連について
}

神厅医科大学産婦人科教室

大学院学生 望 月 真人

性機能, 特に女性々機能と甲状腺機能とか密接な関係にあることは, 実験的にも臨床的にも明らかな事実 である，從つて夫々を支配する性腺刺㦸ホルモン（以下Gと略記）と状㟫刺战ホルモン（以下 TSH と略 記）との間にも関連する点が多いととが容易に予想される。

两者の関連性を論ずるに当つては，先ず夫々の特徵を正確に把握する必要がある，そのうちGについての 研究は近年頓に活潑となり，その生物学的特徽のみならず，化学的性状についても解明された処が少なくな い. 併しながら TSH はGと同じく下垂体性 proteohormone であり, その産生機構にも類似点が多く, と もに糖蛋白であると云われながらも，尚今日その化学的州状はもとより分離抽出法に関しても知る処が少な く，多くの検討すべき余地がある。

そこで私はまずTSH 活性物質について連続式滤紙電気泳動法により豚下垂体から有効成分の分離精製を 試み, その化学的性状の一部を明らかにし, ついでGについて同様の操作を行なつて若干の新知兒を得, そ の詳細を前報に記述したが，茲に更めて両者の関連性について総括する.

\section{1) 滤紙電気泳動条件による相異}

TSH 活性は塩基性溶媒の許で分劃された中央の分劃にのみ存在し, 酸性溶媒で分離した分劃では, TSH 活性は著しく減殺されてしまう(第 2 報, 第 3 報〉。他方 $\mathrm{G}$ 活性は塩基性, 酸性何れの溶媒で分離した場合 でも活性を認めた (第 6 報)。このととから G 活性物質は何れの溶媒でも安定であるに反し，TSH 活性物質 は塩基性溶媒では安定しているが，酸性溶媒中では不安定で生物学的活性が失われる惧れがあると云いうる。 従つて体液中から TSH を分離抽出する場合や精製を行なう場合 G活性物質の分離抽出に常用されている様 な酸性溶媒下の操作は不適当であると推論するととが出来る.

\section{2) 生体内での移動}

ラットに TSH 並びにG 製剤を高濃度に投与した後, その血清を連続式滤紙電気泳動法で分離, 各分劃每: の生物学的活性を検討した処，TSH 活性物質もG活性物質も共に $\gamma$ ーグロブリン分劃にあることを見出した (第 3 報, 第 5 報)。即ち TSH 及びG活性物質は血中に於いてともにr-グロブリンと結合して移行している と考えられる.このことは此の 2 種の proteohormone の化学的近似性を示唆するものであろう.

\section{3) 物理化学的性状の比較}

第 4 報で既述した如く, 私は豚下垂体前葉アセトン粉末より濾紙電気泳動法によつて精製し, 他の tropic hormone を殆んど含まないTSH 活性物質を分離し，てれを超遠心分離法でその分子量を測定した処，沈 降率2.3S，その分子量は約 20000 と算定出来た. Bates が牛の TSH の分子量を約 25000 と報告しているが， 動物の種属によつて多少差異のあるものと思われる．既述した如く一つの製薬会社の TSH 製剤でも製品番 号を買にする場合泳動像に多少の相異のあるととと何等かの関連があるものと思われる (第 2 報).

次にGについては Steelman，S.L. \& A. Segaloff ${ }^{2}$ は羊FSH は25000〜30000, 羊 LH は30000, 人 G は30000 と述べている. 此点からみてGは TSHに比して大きな分子より構成されているものと思われる.

処で私の分離精製した TSH 並びにG活性物質について，その糖成分並びにアミノ酸組成を分析した協同 研究者荒木の研究によると, TSH も G (Köln-G, NIH-FSH, NIH-LH，市販製剤，PMG，HCG）いずれ 
も生物学的活性のある分劃には常に同じ糖を確認しており，TSH 及びG活性物質に共通するこの糖がてれ らホルモンの生物学的作用と何等かの関係を有しているものと推察され,アミノ酸組成では Steelman \& Segaloff がGのそれについて報告している処と略々等しい，此点を併せ考学ると TSH とG とは化学的に極め て近似している糖蛋白で, 唯その分子量に差があるものと云いうる.

\section{4) 両者の Contamination.}

私が行なつた滤紙電気泳動法に上る両物質の分雔精製の結果からみると溶媒を酸性とした場合 TSH 活性 が減弱するから，TSH の Contamination を除外しうるが，併し TSH 活性を減弱しない塩基性溶媒に於 いては若干のG活性が混入する (第 4 報, 第 3 表)。他方 Bates より寄贈された Column chromatography によつて分離精製した牛 TSH 活性物質の G 活性をマウス子宮重量法で検討した私の成績では第 1 表の様に 弱い乍ら，若干のG作用を認めた。

第 1 表 Bates's TSH $の$ G作用検討 (マウス子宮重量法)

\begin{tabular}{c|c|c}
\hline $\begin{array}{c}\text { No. of } \\
\text { rat }\end{array}$ & $\begin{array}{c}\text { Bates's TSH } \\
(\mathrm{mg})\end{array}$ & $\begin{array}{c}\text { Control } \\
(\mathrm{mg})\end{array}$ \\
\hline \hline 1 & 9.7 & 6.5 \\
2 & 9.0 & 6.0 \\
3 & 11.2 & 6.3 \\
4 & 10.5 & 7.0 \\
5 & 11.8 & 6.5 \\
\hline
\end{tabular}

又米国 National Institute of Health (NIH) を通じ て頒布をうけた Emory 大学 Wilhelmi 教授の精製し た羊下垂体性 Gのうち LH は濾紙電気泳動学的に極め て純度の高いととは第 5 報で確認したが，此純度の高 いLH活性物質にも $1 \mathrm{mg}$ 当り 0.015 USP の TSH 作 用を含有しているてとが附記されている。此様て現在 の段階に於いては両物質の分離は極めて困難である。

此分離の困難なととは両物質の化学的性状の近似している点から容易に想像しうるが, 両者の混在が果して 精製上の Contamination であるのか，或は更に間接的な生物学的作用によるものであるかは今後の研究に 俟ちたい.

本論文の要旨は第33回，第34回日本内分泌学会総会及び第 7 回，第 8 回日本産婦人科学会総会に於いて発 表した。

稿を終るに臨み終始御烈篤なる御指導と御校閲を睗わつた恩師植田安雄教授並びに神戸薬大森五、彦博士， 終始有益なる助言を賜わつた本教室赤堀助教授, 林講師, 井上講師に謝意を表します。

又研究上の便宜を与えて下さつた塩野義製薬三宅有博士, 阪大蛋白質研究所坦内博士に深甚な謝意を表し ます.

更に貴重な資料を供与された米国 NIH, Bates, R.W.と P.G. Condoliffe 及び Emory 大学 A.E. Wilhelmi 教授, Köln 大学 Heinrichs 講師, 帝国藏器製薬の各位に感謝致します.

本研究は昭和 35 年度文部省科学研究費の補助の下に行なわれた。

\section{文献}

1) 植田安雄他：日本産科婦人科学会雑誌，13，1，77 (1961).

Recentprogress in Hormone research., XV, 1959.
第1図 Pretiron, Bates's TSH 及び 私の TSH $の$ 水平式滤紙電 気泳動像の比較

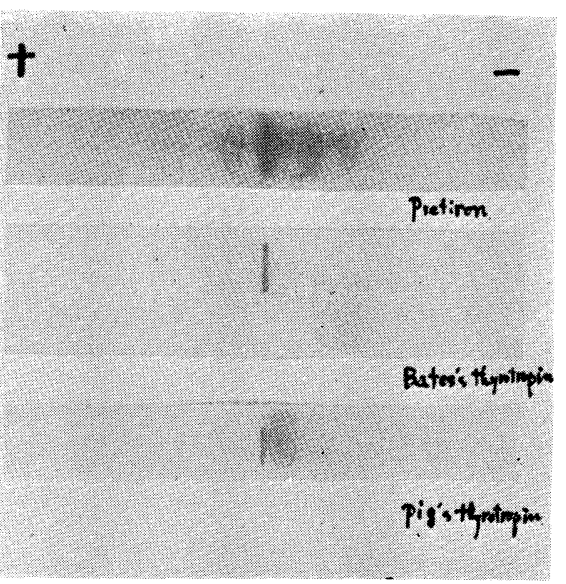

